\title{
UTILIZAÇÃO DO ESBOÇO PARA RECUPERAÇÃO DE IMAGENS DE FACES HUMANAS
}

\begin{abstract}
Dissertação apresentada à Escola de Engenharia de São Carlos da Universidade de São Paulo para obtenção do título de Mestre em Ciências, Programa de Engenharia Elétrica - Área de Concentração: Processamento de Sinais e Instrumentação*.
\end{abstract}

Orientador: Prof. Dr. Adilson Gonzaga

São Carlos

2012

\footnotetext{
"Trata-se da versão corrigida da dissertação. A versão original se encontra disponível na EESC/USP que aloja o Programa de Pós-Graduação de Engenharia Elétrica.
} 
AUTORIZO A REPRODUĈ̃̃ E DIVULGAÇÃO TOTAL OU PARCIAL DESTE TRABALHO, POR QUALQUER MEIO CONVENCIONAL OU ELETRÔNICO, PARA FINS DE ESTUDO E PESQUISA, DESDE QUE CITADA A FONTE.

Ficha catalográfica preparada pela Seção de Tratamento da Informação do Serviço de Biblioteca - EESC/USP

Silva, Leandro Sebastian Pereira da

Utilização do esboço para recuperação de imagens de faces humanas / Leandro Sebastian Pereira da Silva ; orientador Adilson Gonzaga. -- São Carlos, 2012.

Dissertação (Mestrado - Programa de Pós-Graduação em Engenharia Elétrica e Área de Concentração em Processamento de Sinais e Instrumentação) -- Escola de Engenharia de São Carlos da Universidade de São Paulo, 2012 .

1. Retrato falado. 2. Misturograma. 3. Processamento de imagens de faces humanas. I. Título. 
FOLHA DE JULGAMENTO

Candidato: Tecnólogo LEANDRO SEBASTIAN PEREIRA DA SILVA.

Título da dissertação: "Utilização do esboço para recuperação de imagens de faces humanas".

Data da defesa: $10 / 12 / 2012$

Comissão Julgadora:

Resultado:

Prof. Associado Adilson Gonzaga (Orientador)

APROVADO

(Escola de Engenharia de São Carlos/EESC)

Prof. Dr. Osvaldo Severino Junior

APROUADO

(Faculdade de Filosofia, Ciências e Letras de Catanduva/FAFICA)

Prof. Dr. Maurílio Boaventura

APROVADO

(Universidade Estadual "Júlio de Mesquita Filho"/UNESP-São José do Rio Preto)

Coordenador do Programa de Pós-Graduação em Engenharia Elétrica e Presidente da

Comissão de Pós-Graduação:

Prof. Titular Denis Vinicius Coury 

A Deus, por conceder todos os dons, principalmente inteligência e perseverança.

À minha avó Anna, que não teve a oportunidade do estudo, mas muito me ajudou e inspirou.

À Natália, minha noiva, com amor, admiração $e$ gratidão, por sua compreensão, carinho, presença e incansável apoio ao longo do período de elaboração deste trabalho. 



\section{Agradecimentos}

A Deus pelos dons da vida, sabedoria e perseverança.

Ao Dr. Adilson Gonzaga que nos anos de convivência, muito me ensinou e orientou, contribuindo para meu crescimento científico e intelectual.

À Universidade de São Paulo e a todos os funcionários da Escola de Engenharia de São Carlos, pela oportunidade de realização do curso de mestrado.

Aos professores e funcionários do Departamento de Engenharia Elétrica, pelo ensino, em especial aos funcionários da Secretaria de Pós-Graduação pelo trabalho prestado com dedicação e paciência durante estes anos na USP.

Aos meus familiares pelo apoio e amparo. Porto seguro nos momentos mais difíceis. À minha tia Fátima e à minha irmã Ana Cláudia, tanto tenho a agradecer.

Aos colegas de estudos Rubinho, Sergio, Carol, Ana Cláudia, Renata, Mirela e a todos os funcionários do laboratório de Visão Computacional - LAVI, pelos estudos em grupo e imensurável troca de conhecimentos e convívio que me ajudou a reconhecer valiosos amigos.

Finalmente, agradeço a todos aqueles que contribuíram para a elaboração deste trabalho.

Muito Obrigado!

"Não fazemos amigos, reconhecemo-los." 



\section{Resumo}

SILVA, L. S. P. Utilização do esboço para recuperação de imagens de faces humanas. 2012. 80 p. Dissertação (Mestrado) - Escola de Engenharia de São Carlos, Universidade de São Paulo, São Carlos, 2012.

No segmento criminal, uma ferramenta digital capaz de comparar informações sobre suspeitos criminais, restringindo a lista de potenciais criminosos, representa um grande avanço tecnológico. O desafio é conseguir recuperar imagens similares em banco de dados a partir do retrato falado de um suspeito, sendo assim possível localizar as imagens de criminosos no banco de faces da polícia. A importância desse desafio deve-se ao fato que na maioria dos casos, o retrato falado gerado, a partir da descrição verbal de testemunhas é o ponto de partida para o desfecho de muitas investigações. Em vista disto, este trabalho tem por objetivo apresentar um sistema computacional capaz de buscar imagens de faces humanas de um banco de faces através dos esboços das imagens de face, a partir de um retrato falado. Foram feitos retratos falados para comparar com os esboços das imagens das faces humanas presentes em banco de dados e foram recuperadas as mais semelhantes. $\mathrm{Na}$ metodologia proposta, as imagens de face passam por um processamento chamado Misturograma, que resulta no esboço da imagem de face, que é utilizado para se comparar com os retratos falados obtidos. O algoritmo proposto usa distância Euclidiana para comparação de semelhança e wavelets de Haar como descritor das imagens. Foram utilizadas as métricas estatísticas de avaliação de desempenho: Recall X Precision e Cumulative Match Score. A metodologia proposta obteve uma precisão de $95 \%$ de acertos nas buscas realizadas em Cross Validation, dessa forma mostra-se um método viável para recuperação de imagens a partir de retratos falados.

Palavras Chaves: Retrato falado, Misturograma, processamento de imagens de faces humanas. 



\section{Abstract}

SILVA, L. S. P. Application of the sketch to retrieve images of human faces. 2012. 80 p. MSc. Dissertation - School of Engineering of São Carlos, Universidade de São Paulo, São Carlos, 2012.

In the criminal segment, a digital tool able to compare information on criminal suspects, restricting the list of potential criminals, represents a major technological breakthrough. The challenge is to retrieve similar images in the database and thus from the sketch of a suspect you can find images of criminals in the police faces database. The importance of this challenge is due to the fact that in most cases, the sketch generated from the verbal description of witnesses is the starting point for the outcome of many investigations. In view of this, this paper aims to develop a computer system able to search for images of human faces from a database of faces using face images of outlines from a sketch. Sketches were made to compare with the outlines of the images of human faces present in the database and the most similar were retrieved. In the proposed methodology, the face images go through a process called Misturograma, resulting in the outlines of the face image, which is used to compare the obtained sketches. The proposed algorithm uses Euclidean distance to compare the similarity and Haar wavelets as a descriptor of the images. We used the statistical metrics for performance evaluation: Recall X Precision and Cumulative Match Score. The proposed method achieved an accuracy of $95 \%$ in carried out searches in Cross Validation thus proves to be a viable method for recovering images from sketches.

Keywords: Sketch (Spoken portrait), Misturograma, human faces images processing. 



\section{Lista de Figuras}

Figura 2.1: Gráfico de comparação entre os principais métodos biométricos quanto à invasão, precisão, custo e esforço (Adaptado de LU, 2012) 25

Figura 2.2: Caricaturas de (a) Bill Clinton, (b) Albert Einstein e (c) Mona Lisa. Desenhos das faces de (d) George W. Bush e (e) Marilyn Monroe (Fonte: HSU;

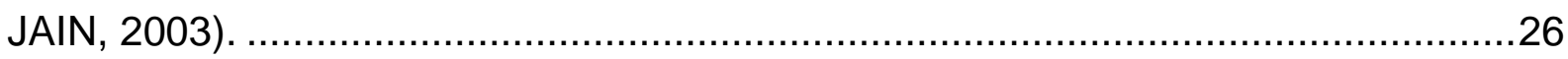

Figura 2.3: Modelo gráfico da face marcada pelos pontos fiduciais ........................28 Figura 3.1: Representação da cor composta pela mistura das cores verde, ciano, vermelho e magenta (Fonte: SEVERINO JR., 2009) 35

Figura 3.2: a) Imagem original e b) Imagem quantizada pelo Misturograma (Fonte: SEVERINO JR., 2009) 38

Figura 3.3: Histograma normalizado das cores quantizadas pelo valor da mistura da Figura 3.2 b (Fonte: SEVERINO JR., 2009) 38

Figura 3.4: Imagem quantizada pela mistura de cores da camada 7 (Fonte: SEVERINO JR., 2009) 39

Figura 3.5: Imagens segmentadas. a) imagem original, b) segmentos de pele da face e c) esboço da face (Fonte: SEVERINO JR., 2009)

Figura 4.1 - Exemplo de imagem de face real obtida do banco de imagens AR (MARTINES; BENAVENTE, 1998). 46

Figura 4.2 - Exemplo de imagem de esboço da face obtida processando-se a imagem original pelo Misturograma.

Figura 4.3 - Exemplo de retrato falado desenvolvido a partir das sub-partes tendo como inspiração a imagem da face original colorida.

Figura 4.4 - Exemplos de sub-partes utilizadas para criação de retratos falados..... 48

Figura 4.5 - Classe composta por 4 poses diferentes da mesma face 49

Figura 4.6 - Imagens segmentadas. a) imagens originais e b) esboço da face .50

Figura 4.7 - Esboços resultantes da mesma classe do banco de faces. .51

Figura 4.8 - a) imagem original e b) imagem gerada com o software de retrato falado utilizando a imagem original como referência

Figura 4.9 - a) imagem original e b) imagem feita utilizando-se as sub-partes da face tendo a imagem original como referência 
Figura 4.10 - a) esboço da face obtido pelo Misturograma e b) imagem gerada com o software de retrato falado utilizando a imagem original como referência 52

Figura 5.1: Gráfico de Cumulative Match Score para o desempenho do sistema.....60 Figura 5.2: Resultado da busca por similaridade das quatro faces mais semelhantes do conjunto de testes, comparando-se o esboço com o retrato falado. $100 \%$ das quatro imagens mais similares pertencem à classe original a qual o retrato falado foi baseado 60

Figura 5.3: Precisão considerando a recuperação das cinco imagens separadamente. 62

Figura 5.4: Precisão média percentual acumulada acrescentando cada imagem da classe desejada, incluindo-se o próprio retrato falado no conjunto de busca. 63 Figura 5.5: Gráfico de Precisão considerando-se apenas as quatro imagens reais da classe para a recuperação a partir do retrato falado correspondente. 64 Figura 5.6: Gráfico de Recall X Precision considerando as quatro imagens reais da classe, mais o próprio retrato falado correspondente à classe como conjunto solução 


\section{Lista de Tabelas}

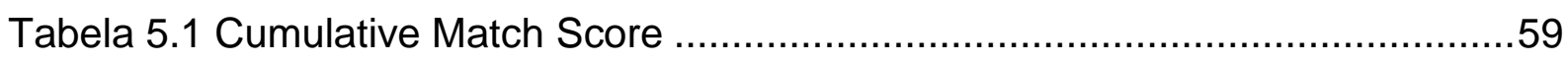

Tabela 5.2 Precisão com 5 imagens recuperadas separadamente...........................62

Tabela 5.3 Precisão com 5 imagens recuperadas cumulativamente .......................62

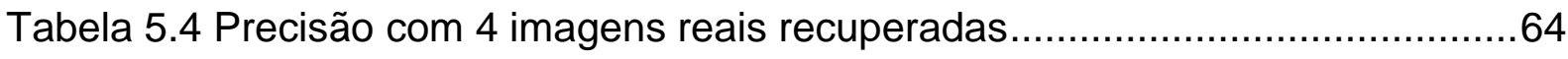

Tabela 5.5 Média dos valores de Recall X Precision das Buscas ............................66

Tabela 5.6 - Precisão top um entre os métodos....................................................68 



\section{Lista de Abreviaturas}

AR: The AR Face Database - banco de imagens faciais denominado AR.

CMS: Cumulative Match Score

CBIR: Contented-Based Image Retrieval - Recuperação de imagens por conteúdo.

MRF: Markov Random Fields - modelo multi-escala.

PCA: Principal Componets Analysis - Análise dos Principais componentes.

RGB: Red Green Blue - modelo de cor concebido com base nos dispositivos gráficos com três cores primárias: vermelho, verde e azul.

RP: Recall X Precision - curva de Refurcação x Precisão. 



\section{Sumário}

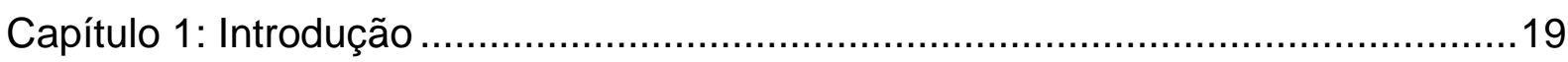

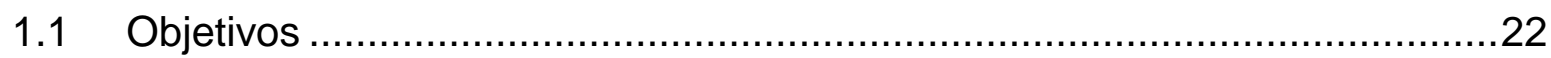

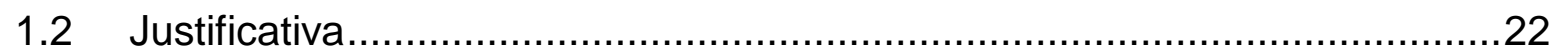

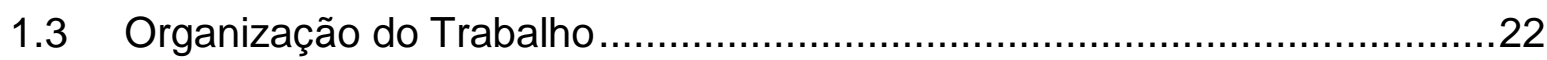

Capítulo 2: Métodos para recuperação de imagens de faces humanas usando

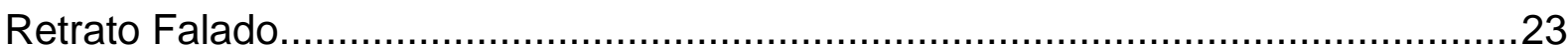

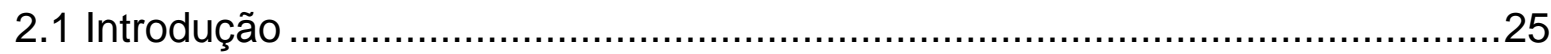

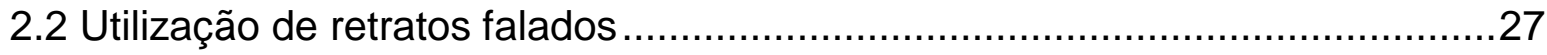

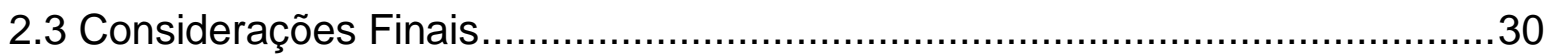

Capítulo 3: Geração do Esboço da face pelo Misturograma ..................................31

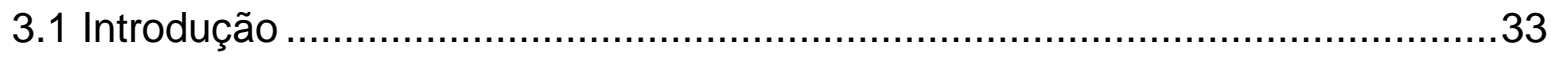

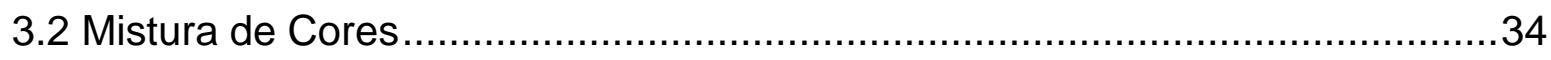

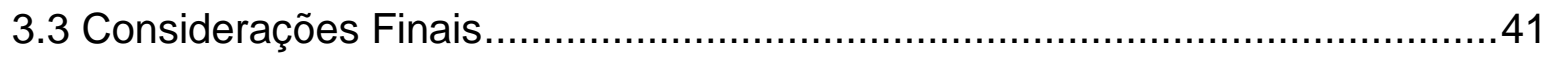

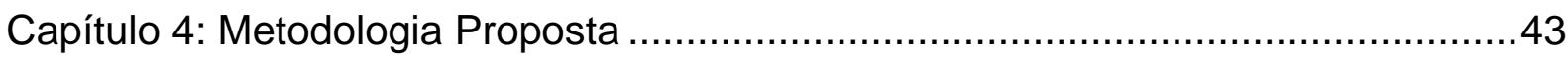

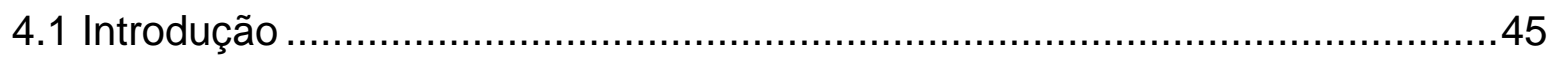

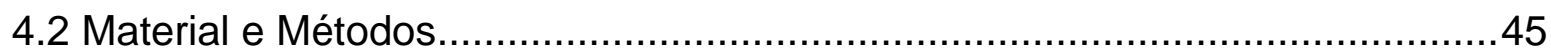

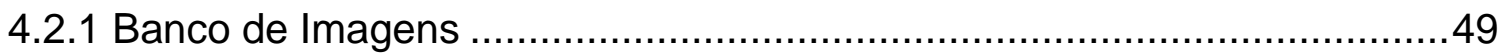

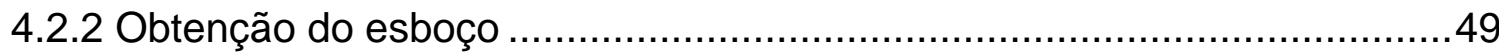

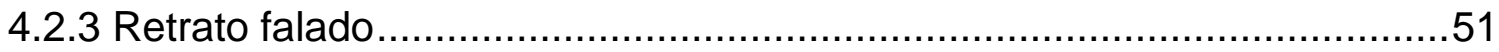

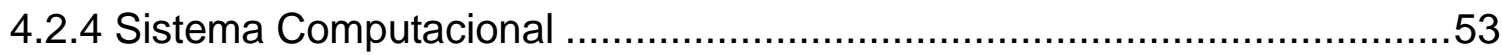

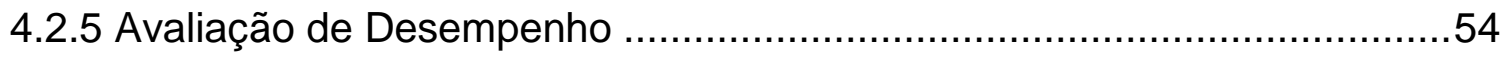

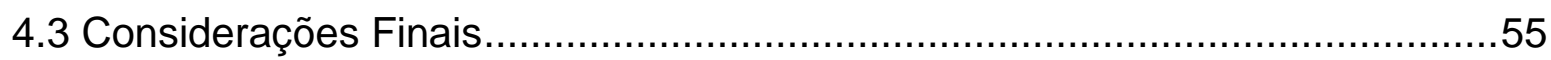

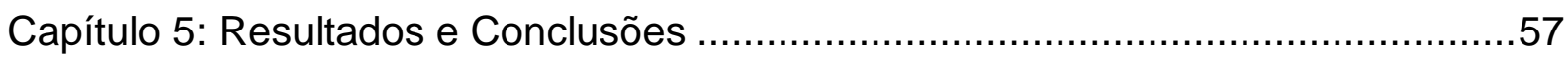

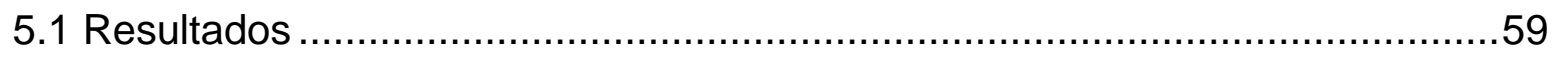


5.2 Discussão

.66

5.3 Conclusões

68

5.4 Contribuições 69

Referências Bibliográficas. 


\section{Capítulo 1}

\section{Introdução}

"Ser homem é ser responsável. É sentir que colabora na construção do mundo." Antoine de Saint-Exupéry 
A área de recuperação de imagens por conteúdo (CBIR - do inglês Contentbased Image Retrieval) tem proporcionado um avanço considerável no campo de Visão Computacional durante a era tecnológica. Este avanço é atribuído à disseminação dos novos produtos tecnológicos gerando a necessidade de administrar grandes quantidades de dados e imagens. Dessa forma, à medida que cresce o volume de imagens armazenadas, cresce também o interesse por sistemas capazes de recuperar informações visuais de maneira eficiente e com maior grau de automação (CAMPO; TRAINA, 2003).

A importância dos sistemas que permitem a recuperação de imagens pelo seu conteúdo (CBIR) tem sido justificada pela necessidade de obter a informação no lugar certo e no tempo adequado, a fim de aumentar a qualidade e a eficiência dos procedimentos em diversas áreas do conhecimento (ERPEN, 2000).

De acordo com Ribeiro (2005), estes sistemas, por sua própria natureza, demandam: a integração de conhecimentos das áreas de processamento de imagens e bases de dados, as pesquisas para o desenvolvimento de técnicas de extração de características, a identificação de objetos salientes, o desenvolvimento de um modelo de indexação eficiente de armazenamento da informação e buscas baseadas no conteúdo, além da formulação de consultas por similaridade.

O ser humano destaca-se na área de recuperação de imagens por conteúdo por ser muito eficiente no reconhecimento de informações apresentadas graficamente, já que o cérebro humano processa melhor informações visuais do que textuais (SANTOS, 2010). Portanto, o ser humano tem grande facilidade em interpretar imagens, o que o torna capaz de associar alguns traços de um desenho ou esboço com os traços de uma pessoa (RIBEIRO, 2005).

Segundo Tang e Wang (2002), por causa dessa associação do ser humano passou-se a utilizar Retratos Falados (RF) para encontrar indivíduos desaparecidos ou procurados, seja para fins forenses (para encontrar criminosos foragidos), ou para fins sociais (reencontrar crianças ou entes desaparecidos).

Os estudos de recuperação de faces têm sido motivados por muitos desafios, dentre eles podem-se ressaltar: as variações da pose do indivíduo quando fotografado, a intensidade da luz, os deslocamentos laterais e rotacionais da cabeça, dentre outros. $\mathrm{Na}$ literatura, nos casos que alcançaram sucesso, foi necessária a combinação de mais do que uma técnica de recuperação de imagens (LU et al., 2003). 


\subsection{Objetivos}

Este trabalho teve por objetivo apresentar um sistema computacional capaz de recuperar imagens de faces humanas em um banco de dados de faces, usando características comuns entre um esboço da imagem de face e um retrato falado.

\subsection{Justificativa}

O Retrato Falado é uma ferramenta muito utilizada na área de segurança forense e para toda a sociedade. Dessa forma, existe uma grande demanda por sistemas de recuperação automática de fotos baseados em retrato falado. Entretanto, são encontrados poucos sistemas na literatura que possuem essa funcionalidade, devido à dificuldade em se construir um banco de retratos falados (TANG; WANG, 2004), e devido às diferenças estruturais existentes entre as imagens a serem comparadas. Portanto, o grande desafio no desenvolvimento desses sistemas está na dificuldade em se comparar uma foto com um desenho de retrato falado, por se tratar de duas imagens distintas (WANG; TANG, 2009).

Um sistema capaz de suprir essa demanda é o que motiva esta pesquisa, tornando-a uma contribuição importante para o reconhecimento de suspeitos criminais e de pessoas desaparecidas.

\subsection{Organização do Trabalho}

Este trabalho está dividido nos seguintes capítulos:

O Capítulo 1 é a Introdução.

O Capítulo 2 apresenta os principais trabalhos e métodos para recuperação de imagens de faces humanas apresentados na literatura.

O capítulo 3 é baseado no Método do Misturograma que possibilitou a comparação computacional entre uma imagem de faces com os desenhos de retrato falado.

O capítulo 4 consiste na descrição da proposta deste trabalho.

No capítulo 5 são apresentados os resultados obtidos e as conclusões. 


\section{Capítulo 2}

\section{Métodos para recuperação de imagens de faces humanas usando retrato falado}




\subsection{Introdução}

Nos últimos anos o processamento e o reconhecimento de imagens de faces têm recebido atenção especial entre as principais técnicas de biometria, reconhecimento de padrões e visão computacional (MATOS, 2011).

Esse interesse se deve à crescente demanda por esse tipo de aplicação no campo forense, sistemas de segurança, vídeo vigilância, autenticação de acesso restrito, reconstrução de faces, recuperação de imagens por conteúdo (CBIR), entretenimento, comunicação visual e multimídia (LIU et al., 2005).

A principal vantagem da identificação facial sobre os outros métodos biométricos, como a impressão digital e o reconhecimento da íris, por exemplo, está na sua aceitação, pois se trata de um método não invasivo. Por esse motivo não exige a cooperação das pessoas, bastando que sejam focalizadas pelas lentes das câmeras de vigilância espalhadas em ambientes públicos (TANG; WANG, 2002).

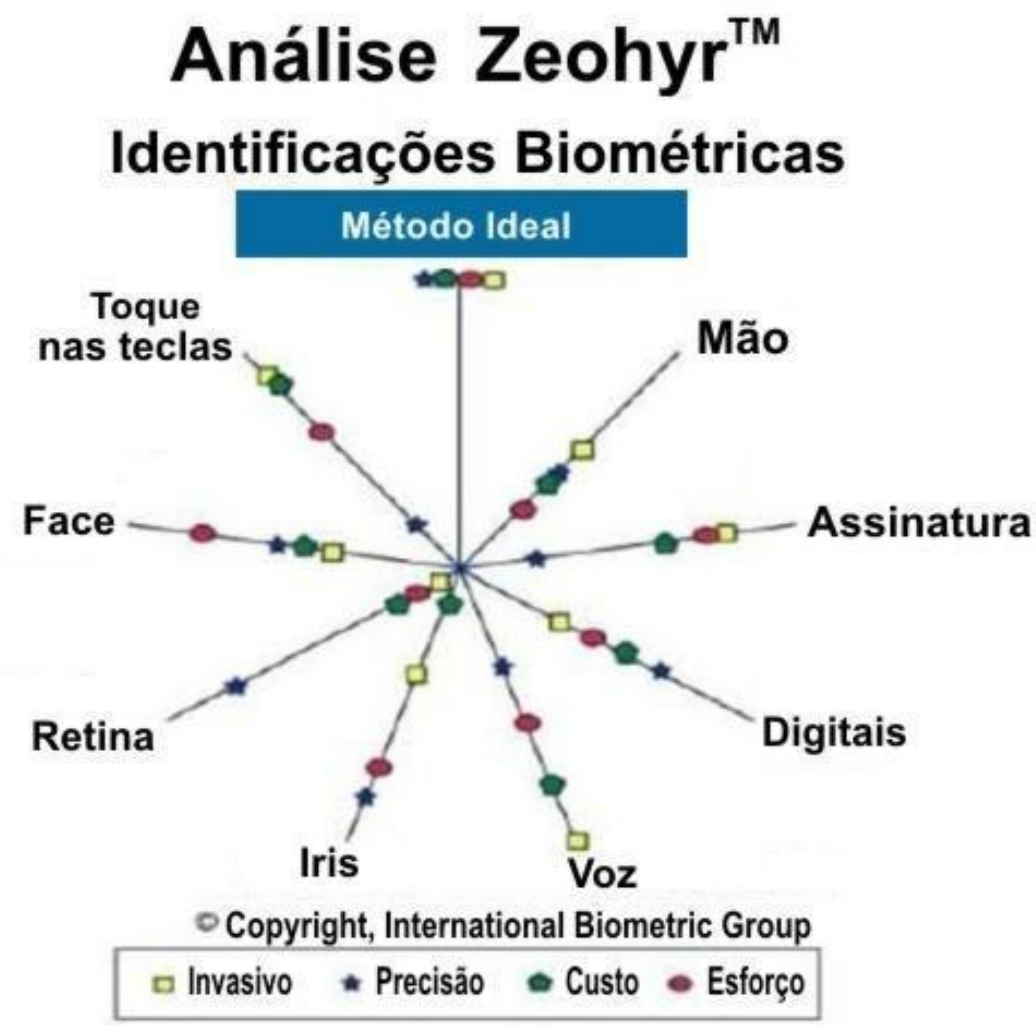

Figura 2.1: Gráfico de comparação entre os principais métodos biométricos quanto à invasão, precisão, custo e esforço (Adaptado de LU, 2012) 
Outro fato que fortalece esse interesse está associado à capacidade humana intrínseca de reconhecer e associar os traços humanos, não exigindo treinamentos específicos para capacitar a correção de erros provenientes do processo (TANG; WANG, 2002; PENTLAND, 2000).

$\mathrm{Na}$ figura 2.1 pode-se observar no gráfico uma comparação entre os principais métodos biométricos e as vantagens da identificação de faces frente aos principais métodos biométricos (LU, 2012).

Quando um crime é cometido, o caminho mais rápido para sua solução e captura dos infratores, propriamente ditos, é através da descrição verbal das testemunhas. Então, um retrato falado é desenhado com objetivo de identificar os criminosos (UHL; LOBO, 1996).

O retrato falado (também conhecido como Sketch, do Inglês) é desenhado por um especialista com base no conjunto de informações visuais fornecido por testemunhas oculares (TANG; WANG, 2003).

A busca baseada em conteúdo de um retrato falado além de auxiliar na localização de potenciais suspeitos, pode também auxiliar o especialista a modificar seu desenho do suspeito interativamente baseado nas fotos similares recuperadas e na opinião das testemunhas (WANG; TANG, 2009).

A capacidade do ser humano de associar características comuns a um grupo de indivíduos auxilia na composição de um retrato falado. A abstração de informações visuais possibilita o cérebro humano classificar os indivíduos em grupos étnicos, determinar raça, a região geográfica de sua origem, o sexo e idade aproximada (LU; JAIN, 2004).

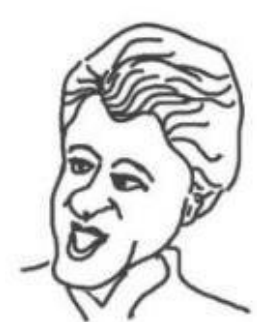

(a)

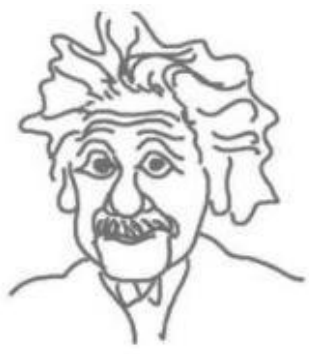

(b)

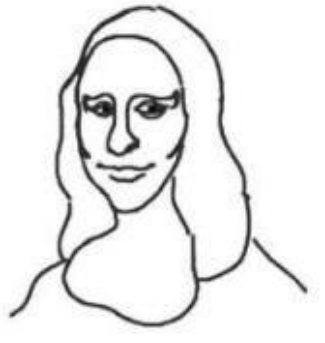

(c)

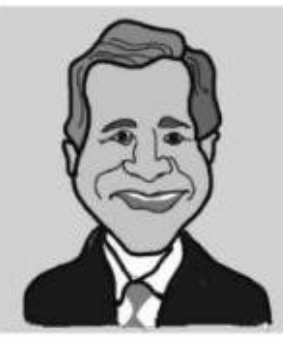

(d)

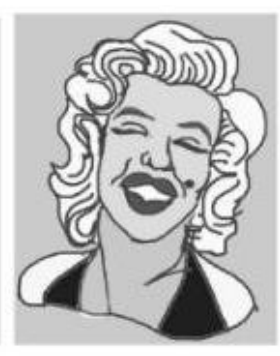

(e)

Figura 2.2: Caricaturas de (a) Bill Clinton, (b) Albert Einstein e (c) Mona Lisa. Desenhos das faces de (d) George W. Bush e (e) Marilyn Monroe (Fonte: HSU; JAIN, 2003). 
O cérebro humano é capaz de identificar facilmente uma face em caricatura, por associar a presença de seus traços marcantes (HSU; JAIN, 2003). Observando a figura 2.2 é possível exercitar essa capacidade, uma vez que poucos traços e rabiscos remetem facilmente às personalidades retratadas. Essa capacidade humana de associar traços e desenhos a uma face inspira o desenvolvimento de sistemas capazes de reproduzir tal capacidade (BENSON; PERRETT, 1991; TANG; WANG, 2004; WANG; TANG, 2009).

Porém, quando se pretende desenhar um retrato falado, uma dificuldade relevante está no fato de se descrever um desconhecido, informações visuais que o cérebro da testemunha só teve contato uma única vez, já o artista que desenha nunca viu e depende de muita habilidade para retratar as informações visuais da testemunha expressas oralmente.

\subsection{Utilização de retratos falados}

Para que se possa utilizar um retrato falado em processos automáticos de reconhecimento de faces é necessária a utilização de mecanismos que possibilitem a comparação gráfica e estrutural entre as duas imagens tão diferentes. A viabilidade para o reconhecimento de faces baseando-se em retratos falados é reduzir a diferença entre as duas modalidades de imagens comparadas no processo de reconhecimento (TANG; WANG, 2003).

Esta dificuldade pode ser explicada pelo fato de não se encontrar na literatura muitos sistemas de reconhecimento de faces a partir de retratos falados nas últimas três décadas, período em que se registra o surgimento de muitas técnicas propostas para reconhecimento de faces (ZHAO; CHELLAPPA, 2003).

Tang e Wang (2003) propõem um algoritmo denominado eigentransformation, sintetizando o retrato falado em um subespaço, separando forma de textura.

O experimento (TANG; WANG, 2003) foi realizado utilizando-se de uma base de 606 faces separadas em três conjuntos: 202 faces, 202 eigenfaces e 202 retratos falados desenhados por artistas especializados em retrato falado. Para cada face existia um retrato falado correspondente, desenhado por um artista. Neste processo a imagem da face foi reconstruída pelo processo chamado pelo autor de eigentransformation, resultando em uma eigenface representada por PCA. 
Utilizando o classificador Bayesiano baseado em eigentransformation, integrando textura e forma como característica, os autores atestaram precisão de $81,3 \%$ para top um e de $97 \%$ para top dez. Para avaliação de eficácia foi utilizada a técnica Cumulative Match Score (CMS), técnica pela qual as imagens do banco são classificadas e ordenadas de acordo com a similaridade de cada uma com a imagem de busca. No topo (top) estão as mais similares. Desta forma, para uma análise estatística, considera-se em quantas vezes a imagem desejada apareceu no topo da similaridade (top um), ou ainda, quantas vezes a imagem desejada estava entre as dez mais similares (top dez).

Em outro trabalho de Tang e Wang (2004) foi proposto um método para transformar as fotos em retrato falado, e os resultados são comparados com dois métodos existentes na literatura: medidas geométricas (BRUNELLI; POGGIO, 1993) e subface, também chamado por eigenface pelos autores (TURK; PENTLAND, 1991).

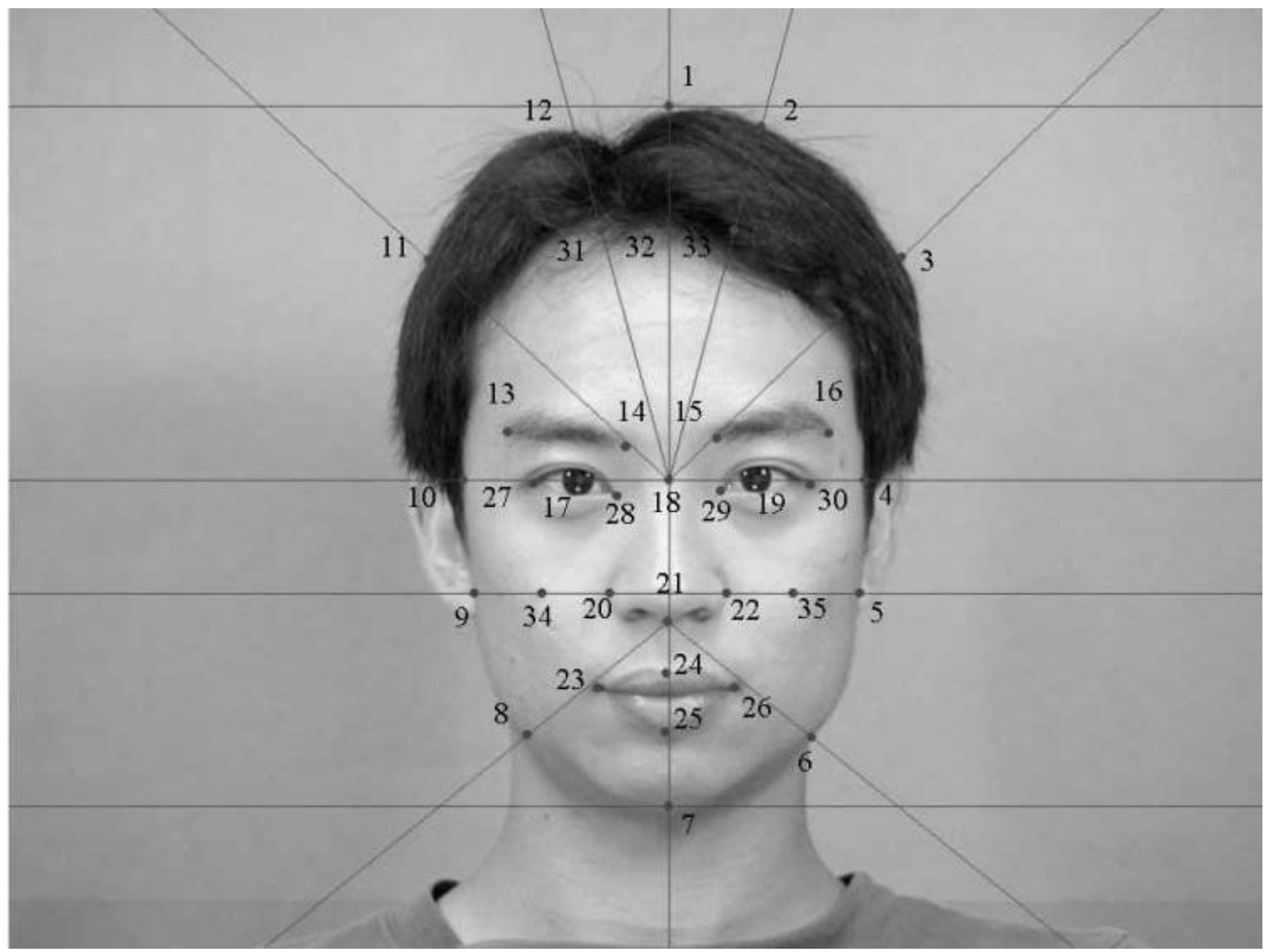

Figura 2.3: Modelo gráfico da face marcada pelos pontos fiduciais (Fonte: TANG; WANG, 2004). 
O método de características geométricas trata de medidas definidas por pontos fiduciais da face de cada indivíduo (BRUNELLI; POGGIO, 1993), conforme pode ser observado na figura 2.4. O ponto forte do método é invariância à textura e à cor, que diferem um retrato falado da imagem original, mas, o ponto fraco é a intolerância às variações de escala das imagens e às variações de expressões da face, que deslocam os pontos pré-definidos (BRUNELLI; POGGIO, 1993). Utilizando CMS para avaliar a eficácia, este método obteve $30 \%$ de precisão na recuperação para top um e $70 \%$ para top dez (TANG; WANG, 2004).

O método de subface é um método clássico de reconhecimento de faces (TURK; PENTLAND, 1991). O método tradicional considera cada face como um grande vetor de característica utilizando a intensidade de cada pixel como uma única característica. Alterações de iluminação, expressão e rotação são apontadas como pontos fracos deste método, pois altera a intensidade e posição do pixel que compõe a imagem. A precisão de recuperação utilizando CMS como avaliador de desempenho foi de $31 \%$ para top um e de $67 \%$ para top dez.

O método proposto por Tang e Wang (2004) chamado de Sketch Transformation compara o retrato falado com a foto modificada dos indivíduos presentes no banco de dados. Essa foto modificada é chamada de pseudo-sketch pelos autores. Na recuperação utilizando-se esta técnica, os autores atestam eficácia de $71 \%$ para top um e de $96 \%$ para top dez, utilizando CMS como avaliador de desempenho.

Em Wang e Tang (2009), os autores propõem uma técnica de síntese e recuperação de retratos falados usando um modelo multi-escala Markov Random Fields (MRF). Esse sistema é composto por três partes: 1) é dada uma foto da face e o desenho (sketch) é sintetizado; 2) é dado um desenho da face (sketch) e a foto é sintetizada; 3) são realizadas as buscas por fotos de faces em banco de dados baseando-se em um retrato falado (sketch) desenhado por um artista. Para o experimento foram adotadas apenas fotos de pose frontal, com iluminação normal, expressões neutras e sem disfarces. Neste caso, a comparação entre a foto e o retrato falado ocorre entre as partes sintetizadas de ambas as imagens, no nível das sub-partes da face (local patches), e não no nível da face total. Por exemplo, a comparação do olho da foto é realizada com o olho do retrato falado, e assim acontece com as outras partes previamente sintetizadas. 
Para viabilizar a transformação da face em retrato falado ou retrato falado em face, a diferença entre as duas imagens foi minimizada. Isso se dá através de um conjunto de treinamento, onde a relação entre o par sketch e foto é estabelecida. Primeiramente as duas sub-partes comparadas são representadas de forma linear através de um vetor de característica (PCA) composto da intensidade de cada pixel das sub-partes. Então os vetores das duas imagens são somados, pixel a pixel e depois o vetor resultante é obtido através da média das duas imagens comparadas.

A recuperação dos vetores das imagens iniciais pode ser obtida desfazendose a soma realizada.

Utilizando a síntese de fotos para o método de multi-escala MRF, os autores atestam eficácia CMS de 96,3\% para top um e de 99,7\% para top dez.

\subsection{Considerações Finais}

Neste capítulo foi apresentado que a identificação facial é um processo biométrico não invasivo com vantajoso custo/benefício, e, por este motivo tem aumentado o interesse por aplicações deste tipo para fins forenses e de segurança. Apesar disso, as aplicações deste tipo que utilizam retratos falados ainda são escassas na literatura provavelmente devido à dificuldade em se construir um banco de dados de retratos falados ou devido à dificuldade em se comparar uma foto com um desenho de retrato falado, por se tratar de duas modalidades distintas. Para se comparar um retrato falado com uma imagem de face real é necessário reduzir a diferença entre as duas modalidades de imagem. 


\section{Capítulo 3}

\section{Geração do Esboço da face pelo Misturograma}




\subsection{Introdução}

A cor transmite informações sobre condições de iluminação sendo esta uma das principais características dos objetos visualizados, dando à visão, propriedades visuais como os contornos das formas e o sombreamento (SEVERINO JR., 2009).

$\mathrm{Na}$ retina do olho humano existem células sensíveis à luz, são os bastonetes e os cones, que transformam a energia absorvida na forma de fótons em impulsos nervosos. Os bastonetes são sensíveis à intensidade luminosa em toda gama de comprimentos de ondas que o olho humano responde. Os cones, por sua vez, são mais sensíveis à luz em determinados intervalos de comprimento de onda.

Os bastonetes proporcionam a detecção das formas dos objetos, enquanto os cones são sensíveis à luz na região do vermelho, do verde e do azul. A diferença entre as respostas dos três tipos de cones (vermelho, verde e azul) permite interpretar diferentes comprimentos de ondas correspondentes a cores diferentes (SEVERINO JR., 2009).

$\mathrm{Na}$ retina humana há cones sensíveis aos comprimentos de onda curta (Short), média (Middle), e longa (Long), tal que para dois cones sensíveis ao comprimento de onda longa existe um cone sensível ao comprimento de onda média. Assim existem cones sensíveis à luz na região do vermelho (faixa de comprimento de onda longo), do verde (faixa de comprimento de onda médio) e do azul (faixa de comprimento de onda curto).

Inspirado nas técnicas de sobreposição de cores utilizadas pelos pintores nas camadas de tintas de diversos matizes para composição de suas telas e quadros (RIBEIRO, 2005) e também a partir da observação do sistema óptico humano composto por cones na retina do olho humano para a interpretação das cores, o Misturograma é uma técnica de processamento de imagens baseada na mistura de cores (SEVERINO JR., 2009).

Trata-se de um método estático de quantização de cores que expressa a proporção das cores preto, azul, verde, ciano, vermelho, magenta, amarelo, e branco obtida pela representação binária da cor que compõe os pixels de uma imagem RGB com 8 bits por canal. Misturograma é o nome dado ao histograma dessa mistura, e, gera planos que interceptam o espaço de cores RGB, definindo o espaço de cor HSM (Hue, Saturation and Mixture) (SEVERINO JR.; GONZAGA, 2005). 
A posição destes planos dentro do cubo RGB é modelada por meio da distribuição dos cones sensíveis aos comprimentos de onda curta (Short), média (Middle) e longa (Long) consideradas para a retina humana. A partir da segmentação das imagens coloridas, os autores demonstram o potencial da técnica através de seus experimentos. O mais importante para aplicação no presente trabalho com retratos falados é a imagem denominada de Esboço da Face, resultante do Misturograma baseando-se apenas na camada mais significativa da mistura de cores (SEVERINO JR.; GONZAGA, 2005).

O Misturograma é utilizado nesta pesquisa para a segmentação das imagens zonas de pele e esboço da imagem, conforme a aplicabilidade sugerida pelo próprio autor (SEVERINO JR., 2009). O modelo implementa a segmentação a partir da composição de cores encontrada na pele humana, classificando os pixels de uma imagem de face em "pele" ou "não pele". Verificando a cor dos pixels presentes na sétima e última camada da mistura de cores é obtida a imagem de esboço da face (SEVERINO JR.; GONZAGA, 2007).

\subsection{Mistura de Cores}

Segundo Severino Jr. (2009), o Misturograma representa a quantização de cada um dos pixels da imagem nas cores preto, azul, verde, ciano, vermelho, magenta, amarelo e branco. Uma cor representada no espaço RGB é constituída pela adição das cores vermelho, verde e azul expressas, respectivamente, pelos componentes $\mathrm{R}, \mathrm{G}$ e $\mathrm{B}$. Uma cor constituída por 24 bits é representada por:

$$
C=\left(R_{7} R_{6} R_{5} R_{4} R_{3} R_{2} R_{1} R_{0}, G_{7} G_{6} G_{5} G_{4} G_{3} G_{2} G_{1} G_{0}, B_{7} B_{6} B_{5} B_{4} B_{3} B_{2} B_{1} B_{0}\right)
$$

onde $C$ é a cor representada e os valores de $R, G$ e $B$ variam de 0 (00000000) a 255 (11111111). A cor $C$ representada desta forma, possui 8 camadas:

$$
K_{i}=\left(R_{i}, G_{i}, B_{i}\right) \text { para } i=0, \ldots, 7
$$

onde $K_{i}$ representa uma mistura das cores expressas pelos componentes $R_{i}, G_{i}$ e $B_{i}$ tal que:

- $K_{i}$ igual a $(0,0,0)$ resulta no preto - ausência de vermelho, verde e azul;

- $K_{i}$ igual a $(0,0,1)$ resulta no azul - presença apenas do azul;

- $K_{i}$ igual a $(0,1,0)$ resulta no verde - presença apenas do verde;

- $K_{i}$ igual a $(1,0,0)$ resulta no vermelho - presença apenas do vermelho; 
- $K_{i}$ igual a $(0,1,1)$ resulta no ciano - mistura do verde e do azul;

- $K_{i}$ igual a $(1,0,1)$ resulta no magenta - mistura do vermelho e do azul;

- $K_{i}$ igual a $(1,1,0)$ resulta no amarelo - mistura do vermelho e do verde;

- $K_{i}$ igual a $(1,1,1)$ resulta no branco- mistura do vermelho, verde e do azul;

O valor máximo representado por 8 bits é 11111111 que equivale a $2^{8}-1$. Deste modo, conclui-se que a cor representada por cada camada $K_{i}$, normalizada pelo valor máximo, possui a proporção:

$$
P_{i}=\frac{2^{i}}{2^{8}-1} \text { para } i=0, \ldots, 7
$$

Em relação à mistura final, onde $\sum_{i=0}^{7} P_{i}=1$.

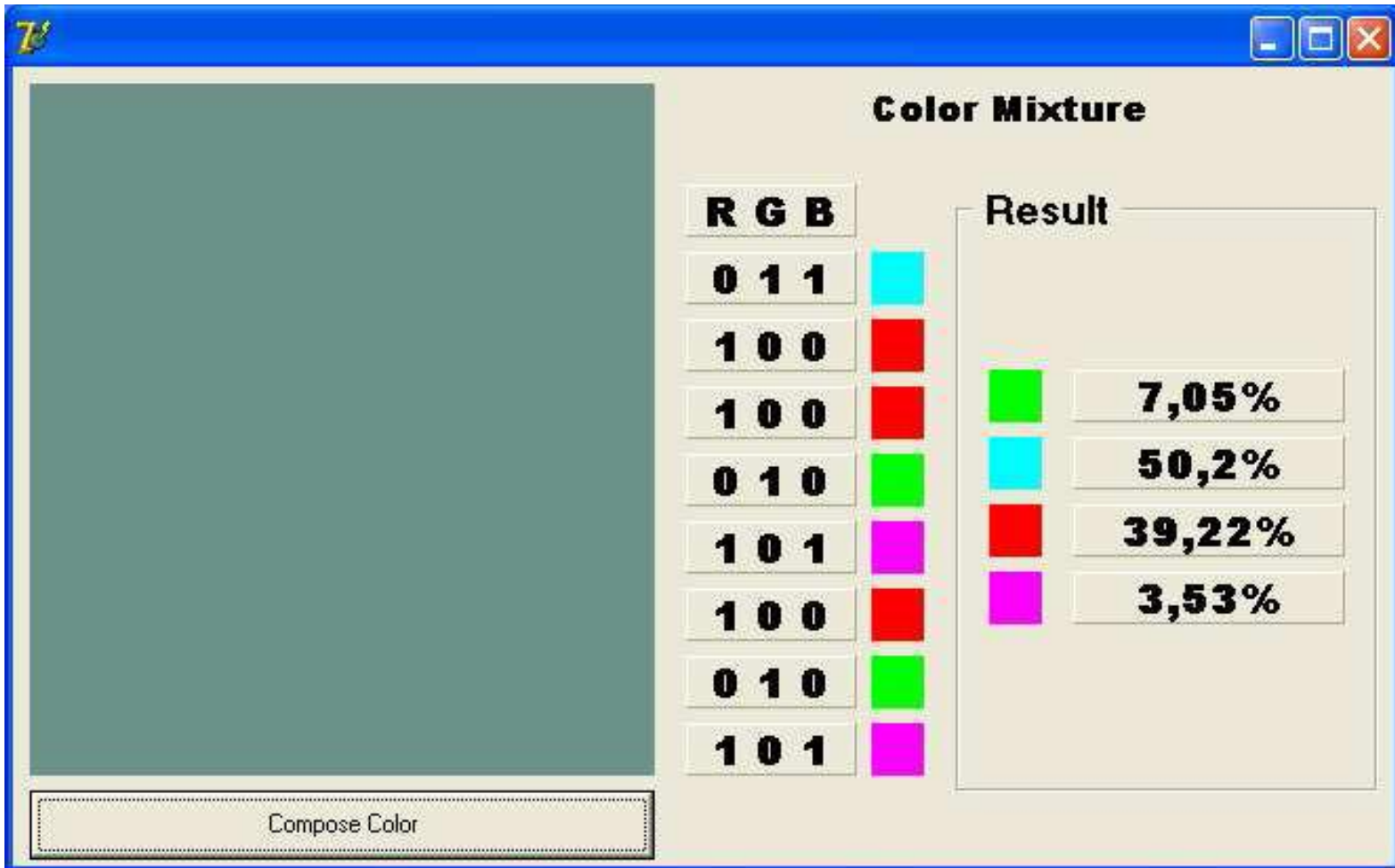

Figura 3.1: Representação da cor composta pela mistura das cores verde, ciano, vermelho e magenta (Fonte: SEVERINO JR., 2009).

A Figura 3.1 mostra o exemplo de uma cor C igual a $(109,146,137)$, que em binário é representada por C igual a ( $01101101,10010010,10001001)$, composta 
pela mistura de 50,2\% da cor ciano, 39,22\% da cor vermelho, $7,05 \%$ da cor verde e $3,53 \%$ da cor magenta determinada da seguinte forma:

- $K_{7}=(0,1,1)$ representa a cor ciano com a proporção $P_{7}=\frac{2^{7}}{\left(2^{8}-1\right)}=0,5020$

- $K_{6}=(1,0,0)$ representa a cor vermelho com a proporção $P_{6}=\frac{2^{6}}{\left(2^{8}-1\right)}=0,2510$

- $K_{5}=(1,0,0)$ representa a cor vermelho com a proporção $P_{5}=\frac{2^{5}}{\left(2^{8}-1\right)}=0,1255$

- $K_{4}=(0,1,0)$ representa a cor verde com a proporção $P_{4}=\frac{2^{4}}{\left(2^{8}-1\right)}=0,0627$

- $K_{3}=(1,0,1)$ representa a cor magenta com a proporção $P_{3}=\frac{2^{3}}{\left(2^{8}-1\right)}=0,0314$

- $K_{2}=(1,0,0)$ representa a cor vermelho com a proporção $P_{2}=\frac{2^{2}}{\left(2^{8}-1\right)}=0,0157$

- $K_{1}=(0,1,0)$ representa a cor verde com a proporção $P_{1}=\frac{2^{1}}{\left(2^{8}-1\right)}=0,0078$

- $K_{0}=(1,0,1)$ representa a cor magenta com a proporção $P_{0}=\frac{2^{0}}{\left(2^{8}-1\right)}=0,0039$

Analisando-se a figura 3.1, pode-se concluir que a mistura apresentada pode ser expressa por uma valor $v$ conforme a equação (3):

$$
v=\sum_{i=0}^{7} \frac{2^{i}\left(\mathrm{R}_{i} 2^{2}+\mathrm{G}_{i} 2^{1}+\mathrm{B}_{i}\right)}{2^{8}-1}
$$

Logo, $v$ é calculado pela soma do decimal que representa o número binário da cor na camada correspondente multiplicado pela sua proporção na mistura final.

$\mathrm{Na}$ figura 3.1 , a cor $C$ igual a $(109,146,137)$ possui $v$ igual a $3,3923(3 \times 0,5020+4 \times 0,3922+2 \times 0,0705+5 \times 0,0353)$.

Assim, qualquer mistura de cores pode ser discretizada a um valor escalar entre 0 e 7 , onde 0 equivale ao valor de RGB igual a $(0,0,0)$ e 7 ao valor RGB igual a $(255,255,255)$. Para isto, foi definido um intervalo $i$, tal que: 
$\mathrm{i}=7 / 8$

onde 7 corresponde ao valor máximo da mistura e 8 ao número de cores definida (preto, azul, ciano, vermelho, magenta, amarelo e branco), e:

- para $0 \leq v<1 \times{ }^{7} / 8$ tem-se $v=0$ que representa o preto;

- para $1 \times 7 / 8 \leq v<2 \times 7 / 8$ tem-se $v=1$ que representa o azul;

- para $2 \times 7 / 8 \leq v<3 \times 7 / 8$ tem-se $v=2$ que representa o verde;

- para $3 \times 7 / 8 \leq v<4 \times 7 / 8$ tem-se $v=3$ que representa o ciano;

- para $4 \times 7 / 8 \leq v<5 \times 7 / 8$ tem-se $v=4$ que representa o vermelho;

- para $5 \times 7 / 8 \leq v<6 \times 7 / 8$ tem-se $v=5$ que representa o magenta;

- para $6 \times 7 / 8 \leq v<7 \times 7 / 8$ tem-se $v=6$ que representa o amarelo;

- para $7 \times 7 / 8 \leq v<8 \times 7 / 8$ tem-se $v=7$ que representa o branco;

Na figura 3.1 , a cor $C$ igual a $(109,146,137)$ possui $v$ igual a 3,3923 que será quantizado para $v$ igual a 3 que representa a cor ciano. Pode-se concluir que o valor $v$ de uma mistura expressa uma transformação do espaço 3D representado pelo espaço RGB para um escalar 1D.

Na figura 3.2 tem-se em a) uma imagem de $288 \times 384$ pixels no formato RGB com 24 bits do banco de faces AR (MARTINEZ; BENAVENTE, 1998) e em b) a mesma imagem quantizada em 8 cores pelo valor $v$ da mistura de cores da imagem.

Portanto, a cor de qualquer pixel de uma imagem RGB poderá ser quantizada nas cores preto, azul, verde, ciano, vermelho, magenta, amarelo e branco, pelo valor $v$ da mistura de cores denominado Misturograma.

Para demonstrar o potencial do Misturograma, verificou-se que na figura 3.2 b), a zona de pele é composta por várias cores (ciano, vermelho, magenta, amarelo).

$\mathrm{Na}$ figura 3.3 pode-se observar um histograma onde as cores presentes na figura $3.2 \mathrm{~b}$ ) encontram-se dispostas graficamente e normalizadas. Os valores representados neste histograma representam a proporção de cada cor na composição da figura $3.2 \mathrm{~b}$ ).

Decidiu-se trabalhar apenas com a mistura de cores da camada 7 (ver equação 1) que corresponde ao bit mais significativo da cor de cada pixel da imagem. 


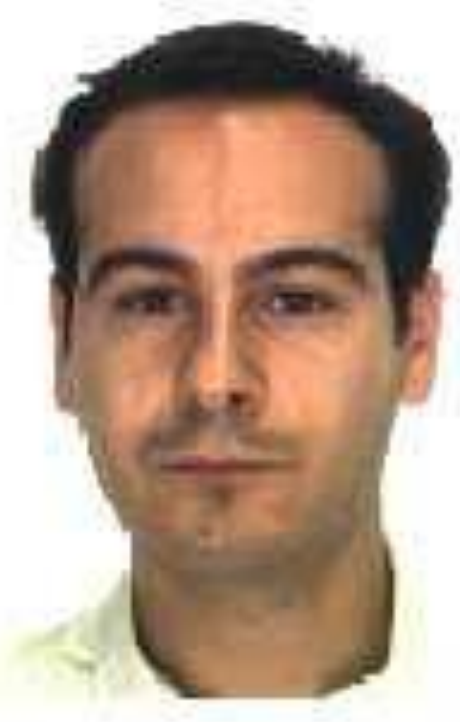

a)

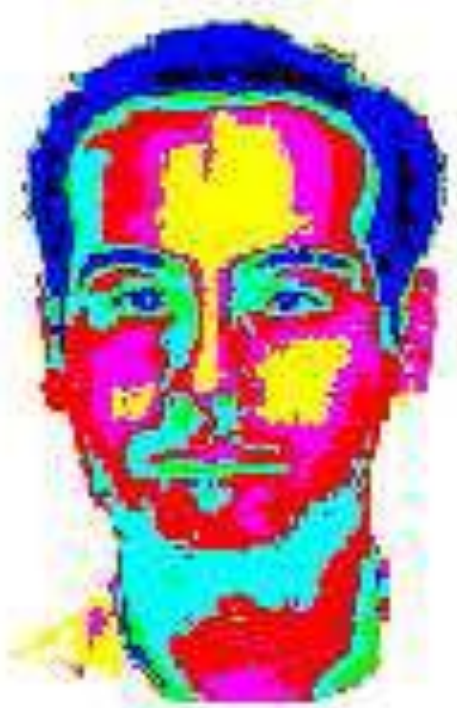

b)

Figura 3.2: a) Imagem original e b) Imagem quantizada pelo Misturograma (Fonte: SEVERINO JR., 2009).

\section{Misturograma}

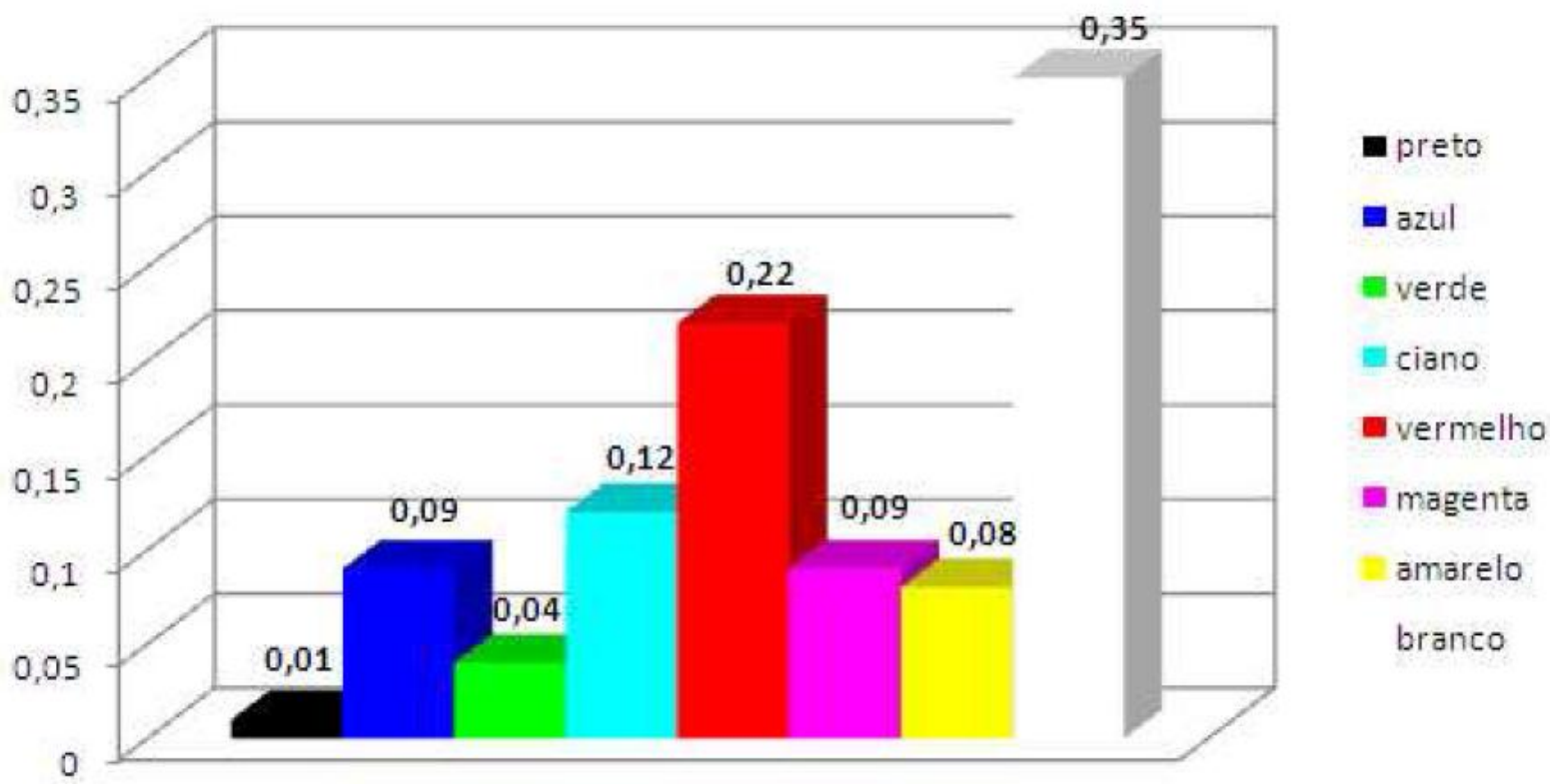

Figura 3.3: Histograma normalizado das cores quantizadas pelo valor da mistura da Figura $3.2 \mathrm{~b}$ (Fonte: SEVERINO JR., 2009). 
Na figura 3.4 é apresentada a mistura de cores da imagem correspondente à camada 7 isoladamente.

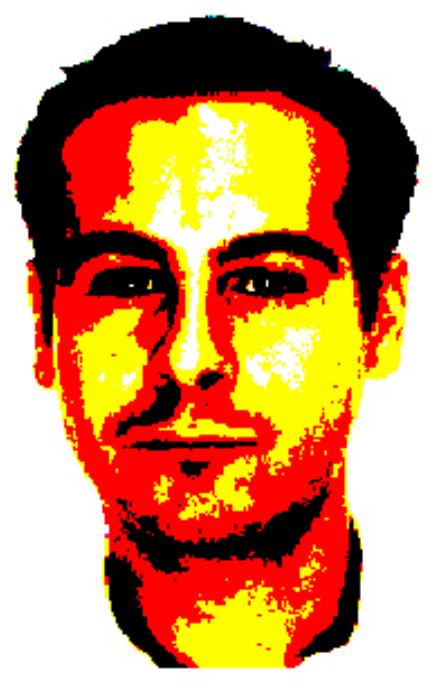

Figura 3.4: Imagem quantizada pela mistura de cores da camada 7 (Fonte: SEVERINO JR., 2009).

De acordo com Severino Jr. e Gonzaga (2007), a pele humana é constituída de pigmentos de diferentes misturas de cores, porém, a porção de face correspondente ao cabelo, sobrancelhas, olhos e barba, tornam-se facilmente identificadas pelo preto. Subtraindo as porções de pele destas imagens, a imagem resultante é um esboço que traz os traços e contornos principais da face inicial. $O$ esboço é uma imagem composta apenas de pixels de cor preta e visualmente semelhante a um retrato falado da face inicial. Na figura 3.5 pode-se observar o processo de decomposição pelo qual se obtém a imagem de esboço: a imagem original na coluna a), o resultado da separação do segmento de pele na coluna b) e o respectivo esboço composto pela cor preta dos contornos da face inicial na coluna c).

A imagem de esboço resultante do processo do Misturograma assemelha-se a um retrato falado da face processada. Por ser um processo automático, torna-se uma opção vantajosa para a comparação com uma imagem de retrato falado convencional ou criada por processos originados de programas específicos. Esta imagem resultante do Misturograma será utilizada no presente trabalho. 

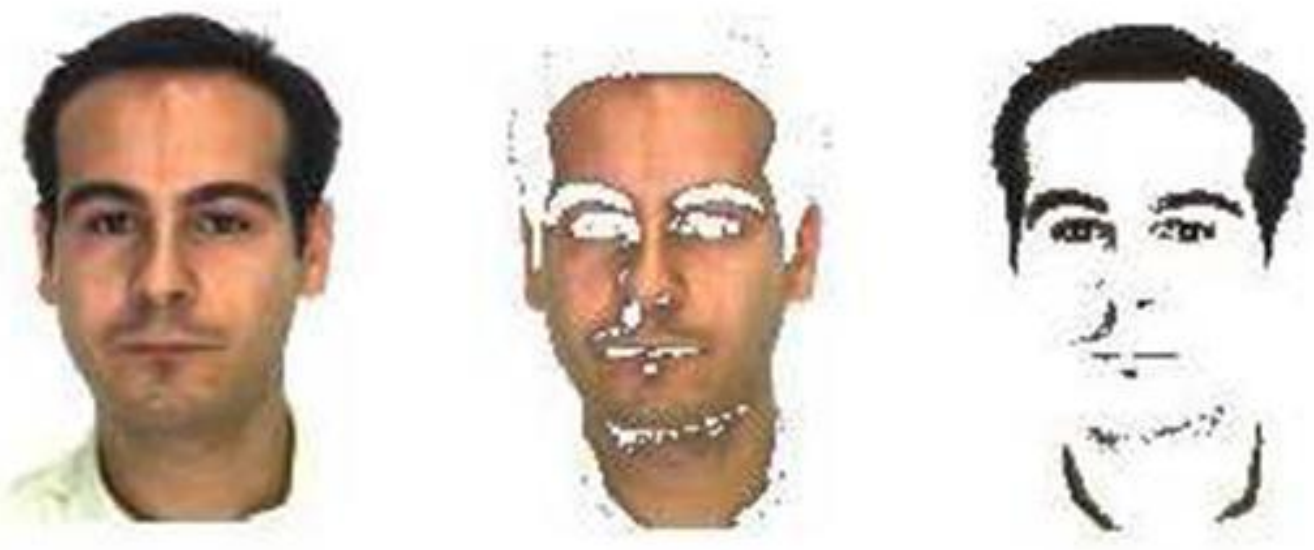

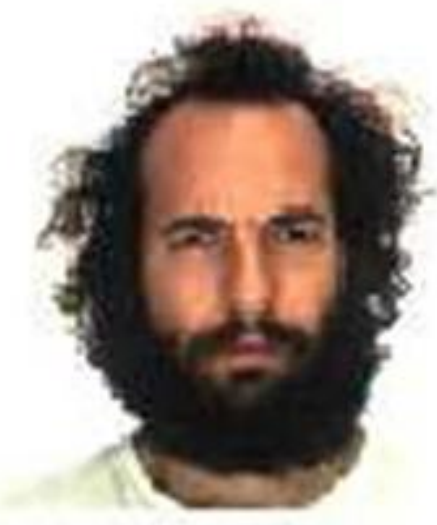

a)

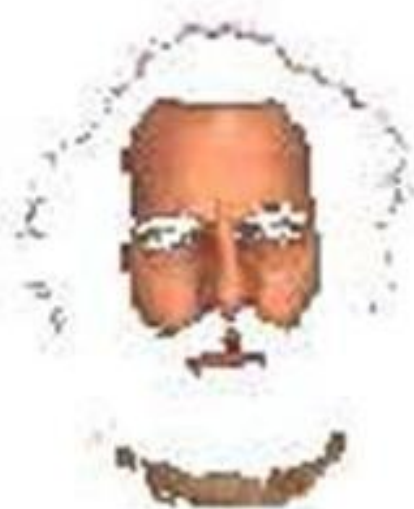

b)
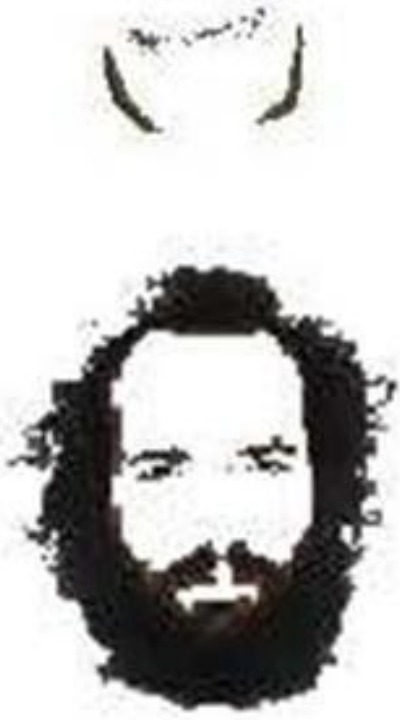

c)

Figura 3.5: Imagens segmentadas. a) imagem original, b) segmentos de pele da face e c) esboço da face (Fonte: SEVERINO JR., 2009).

A vantagem do Misturograma frente aos outros métodos tradicionais de quantização de cores na segmentação de imagens está na redução do tempo de processamento das imagens. Isso ocorre por utilizar-se de apenas oito cores no procedimento (SEVERINO JR., 2009). Além disso, mostrou-se uma forma simples e automática para obtenção do esboço da imagem original sem a interferência humana no processo. 


\subsection{Considerações Finais}

Neste capítulo foi apresentado o Misturograma, uma técnica simples e automática de processamento de imagens que subdivide a imagem colorida nas camadas de cores que a compõe. A camada 7 corresponde ao bit mais significativo da cor de cada pixel da imagem. Segmentando a imagem obtida nesta camada e separando-se a zona de pele dos pixels de cor preta desta imagem obtém-se o esboço da face, que se assemelha ao retrato falado. A vantagem desse método é a redução do tempo de processamento das imagens, por utilizar apenas oito cores no procedimento, além de tornar a imagem colorida comparável com a imagem de retrato falado. 


\section{Capítulo 4}

\section{Metodologia}

"A satisfação está no esforço feito para alcançar o objetivo, e não em tê-lo alcançado." 


\subsection{Introdução}

O cérebro humano, através do seu sistema visual é muito eficiente no reconhecimento de informações apresentadas graficamente, portanto, tem uma grande facilidade em interpretar imagens, sendo capaz de associar alguns traços de um desenho ou esboço com os traços de uma pessoa (TANG; WANG, 2002).

No processo de busca por similaridade, as imagens são submetidas inicialmente à extração de características. Para obter um melhor resultado, essas características devem ser capazes de descrever as imagens referidas. Então, quando o usuário solicita uma consulta por similaridade, deve existir um subconjunto das características que descreve o aspecto da imagem em que o usuário está interessado. Quando o usuário indica as respostas que lhe são relevantes dentre as respostas de uma consulta, as características dessas imagens que descrevem o aspecto em que o usuário está interessado devem estar com valores próximos entre si, enquanto as características que não estão vinculadas a este aspecto devem apresentar faixas de variação diferentes (CAMPO; TRAINA, 2003).

Esse sistema busca: agilizar os processos de investigação policial na identificação e procura de criminosos através de retratos falados feitos a partir da descrição das vítimas ou testemunhas; auxiliar nos processos de identificação e busca de pessoas desaparecidas que tenham seu retrato falado feito a partir da descrição de parentes e conhecidos, uma vez que o retrato falado pode ser mais eficiente que fotos antigas por conservar as características invariantes ao envelhecimento (traços principais), em casos onde a foto original possa não ser tão eficaz; além de disponibilizar um mecanismo de fácil processamento de busca em grandes bancos de dados de domínio público como a internet, por exemplo.

\subsection{Material e Métodos}

O banco de imagens utilizado é composto de 536 imagens de faces presentes no banco de imagens AR (MARTINEZ; BENAVENTE, 1998).

A figura 4.1 apresenta um exemplo de imagem de face do banco de imagens AR. Outras imagens utilizadas no experimento podem ser conferidas no apêndice A. 


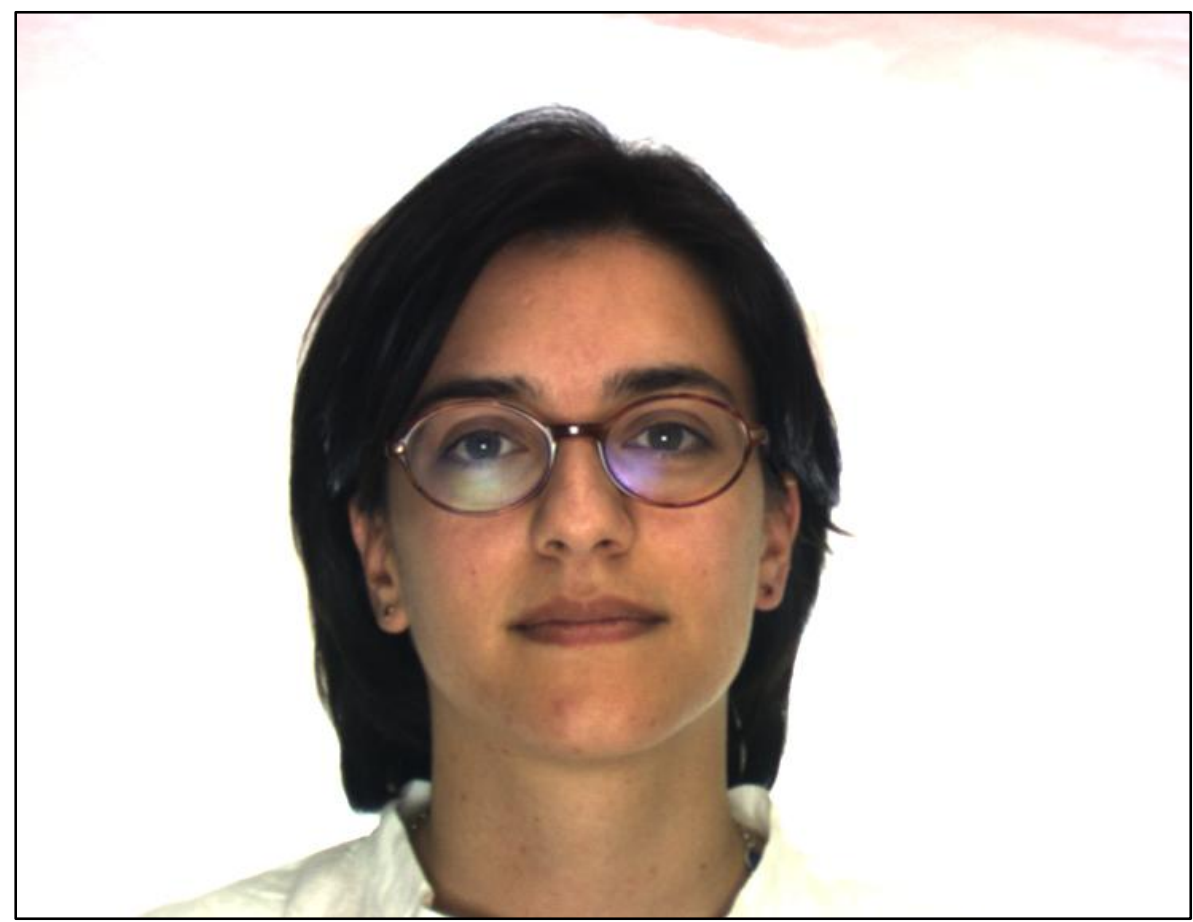

Figura 4.1 - Exemplo de imagem de face real obtida do banco de imagens AR (MARTINES; BENAVENTE, 1998).

Para a redução da diferença estrutural entre as imagens de uma face e o seu respectivo retrato falado, cada imagem presente no banco AR (MARTINEZ; BENAVENTE, 1998) foi submetida ao processamento do Misturograma (SEVERINO JR., 2009). Deste processamento resultaram as imagens de esboço da face, utilizadas para comparação com os retratos falados nas buscas.

A figura 4.2 apresenta um exemplo de imagem esboço obtida processando-se a figura 4.1 pelo Misturograma. Outras imagens de esboço obtidas após o processamento das imagens originais pelo Misturograma podem ser conferidas no apêndice B.

Para verificar a capacidade computacional de se comparar imagens de retrato falado com as imagens esboço obtidas pelo processamento das imagens de faces, foi desenvolvido um sistema no MATLAB 7.0 que combina técnicas de CBIR (CAMPO; TRAINA, 2003; SILVA; TRAINA, 2006; GRACIOSO et al., 2006), com o descritor baseado na Transformada wavelet de Haar (SILVA; TRAINA, 2006; GRACIOSO et al., 2006) como extrator de características. A distância Euclidiana foi utilizada para comparação de similaridade entre os vetores de características gerados. Uma imagem de retrato falado foi dada como entrada de cada 
processamento do sistema, que, por sua vez, devolveu como saída, as imagens de face mais semelhantes ao retrato falado encontradas no banco de dados.

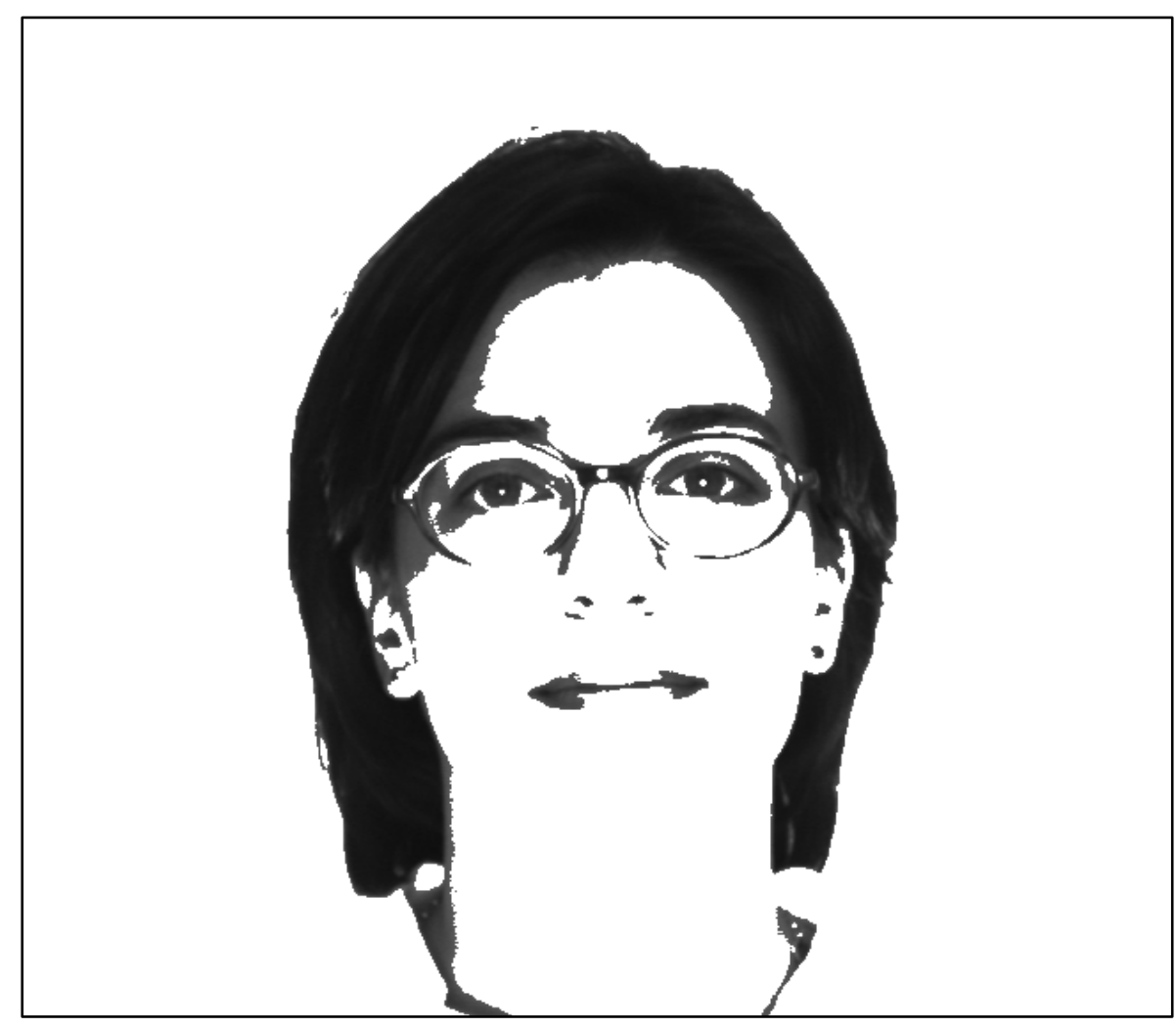

Figura 4.2 - Exemplo de imagem de esboço da face obtida processando-se a imagem original pelo Misturograma.

Para o desenvolvimento dos retratos falados, foi utilizado o software específico Photocomposerplus (MARTINS, 2003 a; 2003 b; 2005 a; 2005 b) e softwares comerciais utilizados para processar imagens, como o Photoshop, Corel Draw e Ms Paint. Os retratos falados foram elaborados por voluntários com inspiração nas imagens originais do banco de faces AR (MARTINEZ; BENAVENTE, 1998).

A figura 4.3 apresenta um exemplo de imagem de retrato falado criada a partir das sub-partes (ver sub-partes na figura 4.4) com um software de edição de imagens tendo como inspiração a imagem original da figura 4.1. Mais imagens de retrato falado como esta da figura 4.3 podem ser conferidas no apêndice $C$. 


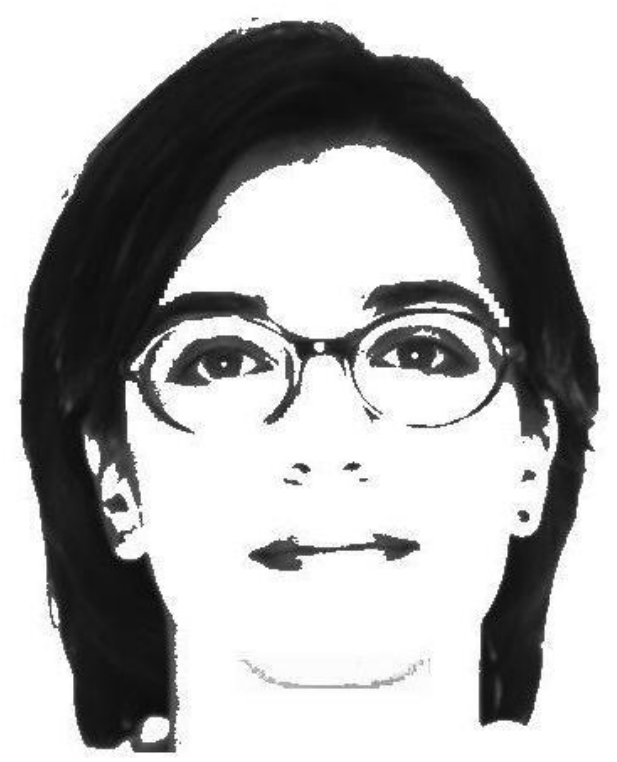

Figura 4.3 - Exemplo de retrato falado desenvolvido a partir das sub-partes tendo como inspiração a imagem da face original colorida.

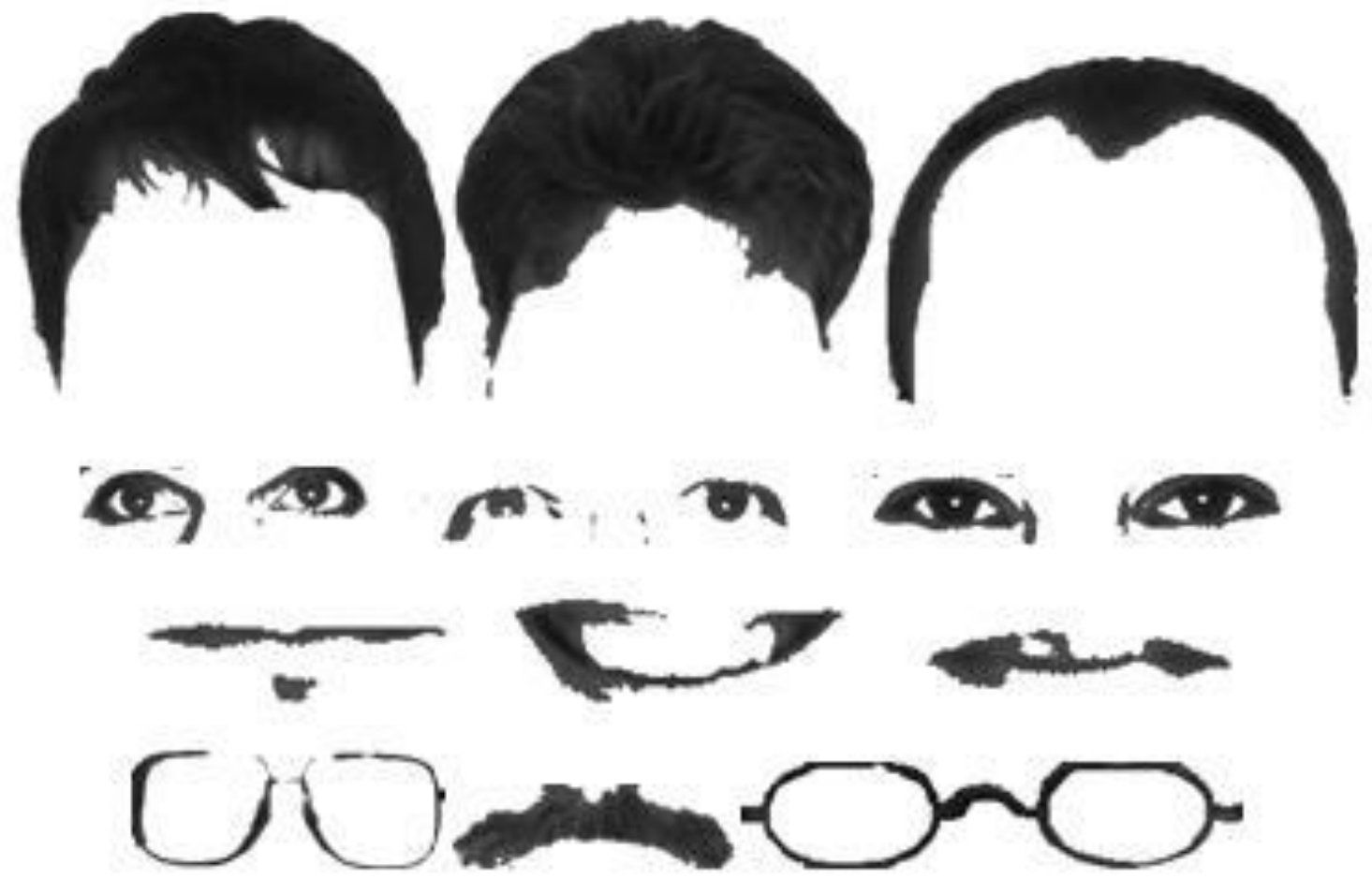

Figura 4.4 - Exemplos de sub-partes utilizadas para criação de retratos falados.

Para avaliar o desempenho da metodologia proposta foram utilizadas as curvas Recall X Precision e Cumulative Match Score (GONZAGA, 2008). 
Os itens de material e métodos apresentados serão descritos com mais detalhes a seguir.

\subsubsection{Banco de Imagens}

O banco de faces utilizado como base do experimento foi composto a partir do banco de faces AR (MARTINEZ; BENAVENTE,1998), formado por imagens de faces humanas reais e coloridas de homens e mulheres ocidentais, de raça predominantemente branca.

As imagens foram selecionadas de forma aleatória e sem obedecer a critérios específicos. Desta forma a sua composição totaliza 536 faces, das quais 304 pertencentes a indivíduos do sexo masculino e 232 pertencentes a indivíduos do sexo feminino.

Cada indivíduo presente no banco de imagens está representado por 4 poses diferentes, e por denominação, cada indivíduo representa uma classe de imagens do banco, como pode ser observado na figura 4.5.

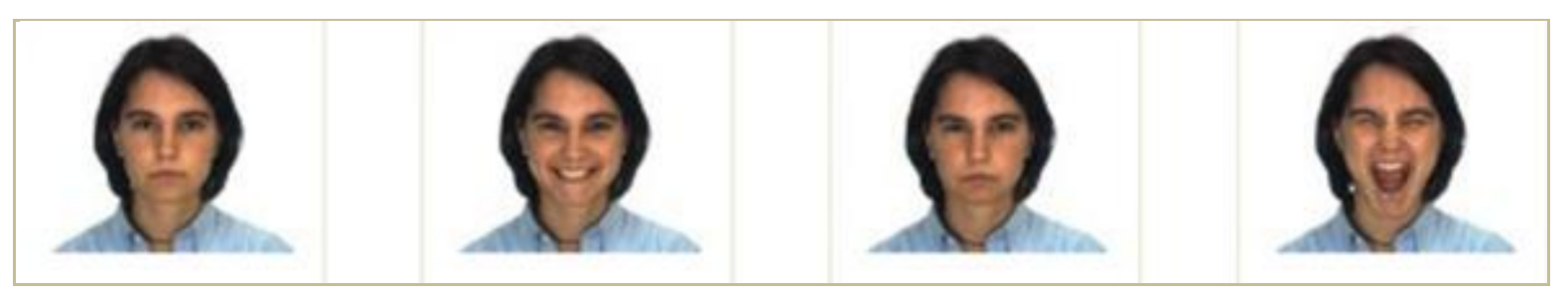

Figura 4.5 - Classe composta por 4 poses diferentes da mesma face.

Deste modo, as 536 imagens estão subdivididas em 134 classes diferentes. Das quais 76 classes pertencem a indivíduos do sexo masculino e 58 classes pertencentes a indivíduos do sexo feminino.

\subsubsection{Obtenção do esboço}

A obtenção da imagem de esboço exerceu um papel fundamental na viabilização deste experimento, pois foi através da obtenção desta que se tornou possível a comparação entre uma imagem de face e outra imagem de retrato falado. 
As faces do banco de imagem foram submetidas ao Misturograma (SEVERINO JR.; GONZAGA, 2006), destacado no capítulo 3 deste trabalho. O Misturograma é responsável por segmentar as imagens coloridas que contém as faces dos indivíduos. Essa ferramenta reúne as características visuais das fotografias de face em um traçado básico, aproximando a imagem original de um retrato falado.

Observa-se na figura 4.6 a seqüência de duas imagens de face seguidas pelas suas respectivas imagens esboço resultantes do processo do Misturograma. Estas imagens resultantes foram formadas a partir da segmentação da camada 7 pelos pixels de cor preta, que será utilizada como imagem de busca.

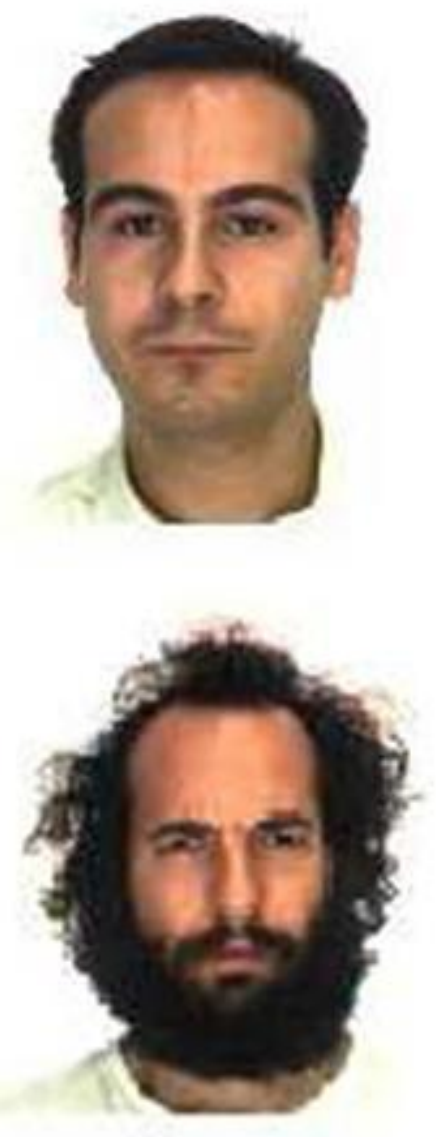

a)
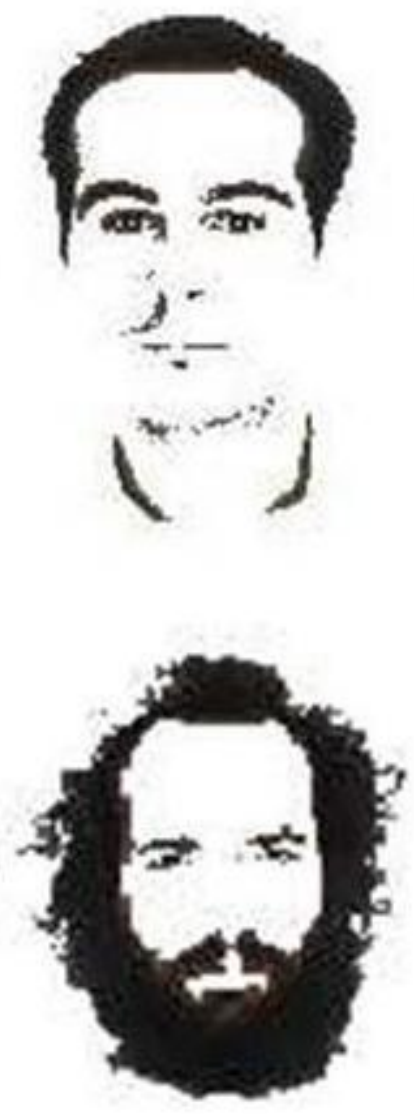

b)

Figura 4.6 - Imagens segmentadas. a) imagens originais e b) esboço da face. 
Foram obtidas 536 imagens esboço indexadas a partir das 536 faces correspondentes do banco de imagens original, conforme exemplo exibido na figura 4.7.

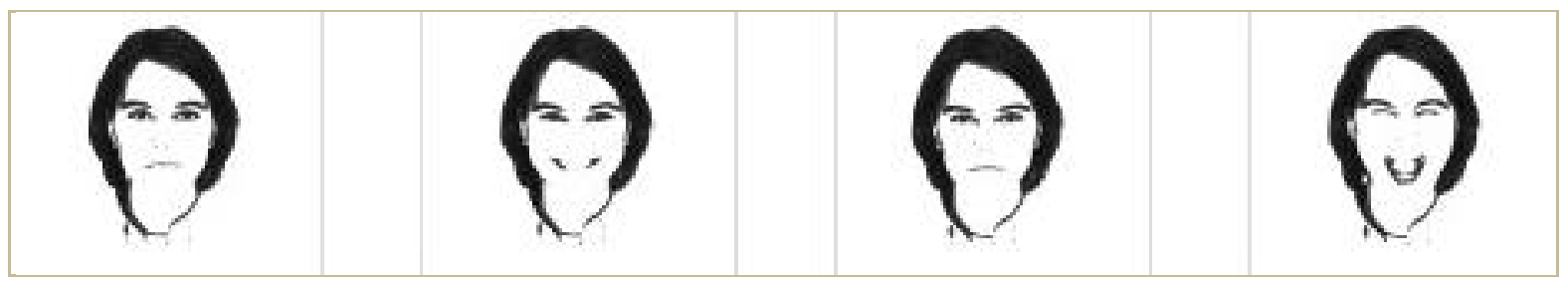

Figura 4.7 - Esboços resultantes da mesma classe do banco de faces.

\subsubsection{Retrato falado}

Utilizando-se o software específico para geração de retrato falado, Photocomposerplus (MARTINS, 2003), foram gerados retratos falados conforme exemplo na figura 4.8, inspirado na imagem de face presente no banco de faces AR.

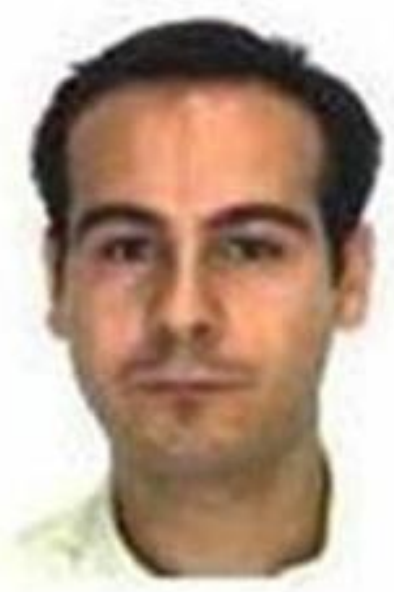

a)

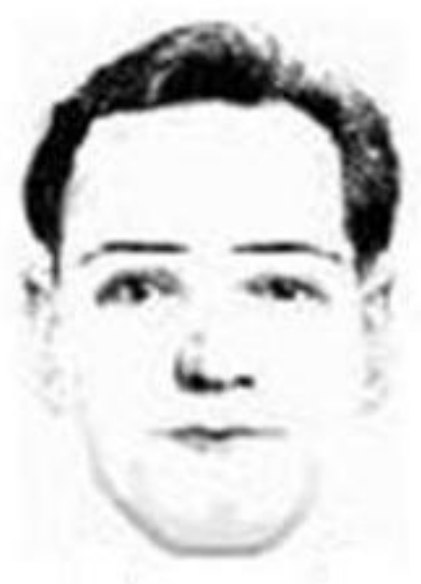

b)

Figura 4.8 - a) imagem original e b) imagem gerada com o software de retrato falado utilizando a imagem original como referência.

Inspirado no mecanismo e no procedimento utilizado para geração de retratos falados no Photocomposerplus (MARTINS, 2003), foi criado um banco de sub-partes da face, com bocas, olhos, cabelos pré-criados, com objetivo de facilitar o desenho 
de retrato falado. Isso possibilitou que uma pessoa sem habilidade específica para desenhos, pudesse desenhar um retrato falado da face original, de forma mais simples. Pode-se observar o exemplo de sub-partes na figura 4.4.

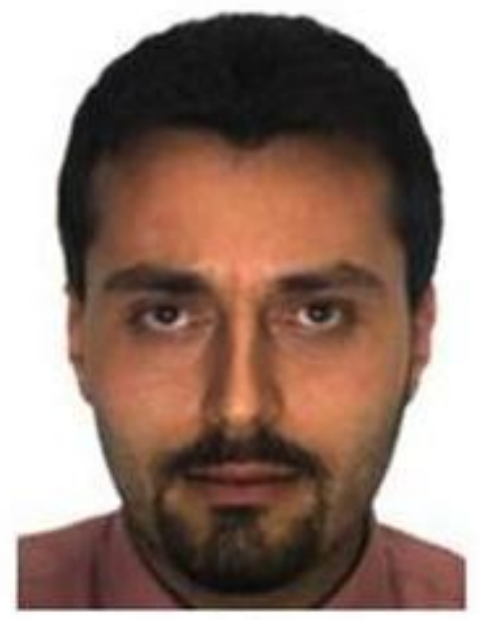

a)

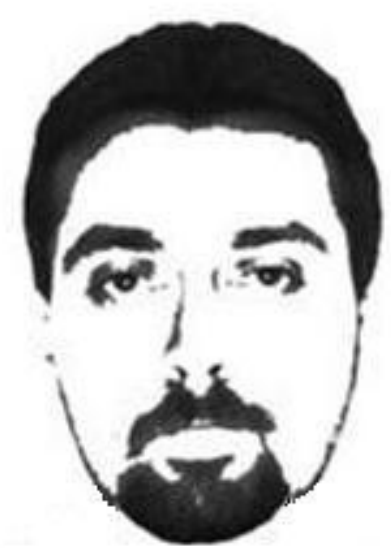

b)

Figura 4.9 - a) imagem original e b) imagem feita utilizando-se as sub-partes da face tendo a imagem original como referência.

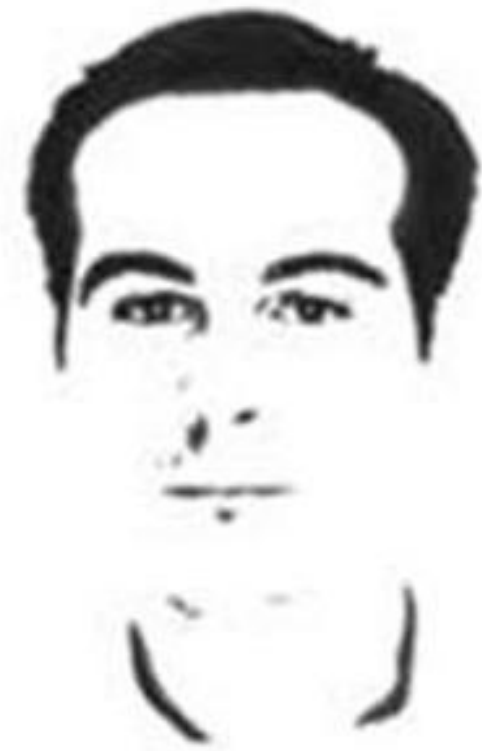

a)

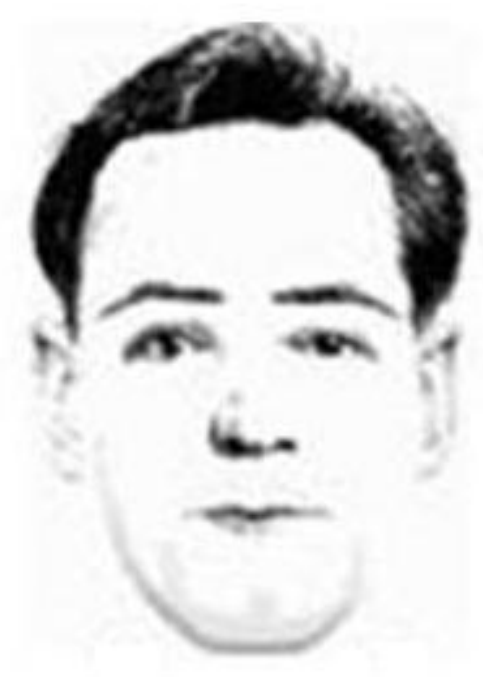

b)

Figura 4.10 - a) esboço da face obtido pelo Misturograma e b) imagem gerada com o software de retrato falado utilizando a imagem original como referência. 
Na figura 4.9 pode-se observar a imagem de face a) e o seu respectivo retrato falado construído a partir das sub-partes b).

Na figura 4.10 é possível visualizar as duas imagens que serão comparadas, a primeira resultante do método do Misturograma, e a segunda, de um retrato falado, elaborado a partir do software de retrato falado (MARTINS, 2003) tomando por base as características do indivíduo na imagem original.

\subsubsection{Sistema Computacional}

Para a comparação entre as imagens resultantes, foi desenvolvido um sistema de busca baseado em conteúdo, que utiliza a transformada wavelet de Haar como descritor. As transformadas wavelet sempre se mostraram uma alternativa eficiente para geração de características em um sistema de CBIR, devido à considerável compressão de dados das imagens digitais, além de permitir um alto grau de automação, ou seja, grande parte do processo sem que haja necessidade de interferência humana* (SILVA; TRAINA, 2006).

Neste caso, as imagens processadas são comprimidas por wavelet de Haar até seu sétimo nível, reduzindo a dimensão e, portanto, o tempo de processamento, sem perda significativa do desempenho.

A partir da imagem de retrato falado, inserida pelo usuário, o sistema realiza a busca por similaridades em uma base de imagens esboço, obtidas a partir da base de imagens faciais.

A Distância Euclidiana foi utilizada para a comparação de similaridade entre a imagem de retrato falado com as outras da base, uma vez que não é objetivo deste trabalho otimizar o resultado de busca (CAMPO; TRAINA, 2003; SILVA; TRAINA, 2006), e sim mostrar a possibilidade de se utilizar um retrato falado como imagem de busca de imagens originais e coloridas.

Durante o processamento, cada imagem presente no banco foi classificada com um índice de similaridade com a imagem de entrada, que no caso é o retrato falado. A partir desse índice as imagens foram organizadas em um ranking de similaridade, que as ordena da mais similar até a menos similar. Como saída o

\footnotetext{
Foge ao escopo deste trabalho a análise de eficiência de diferentes extratores de características para a recuperação baseada em conteúdo das imagens de retrato falado.
} 
sistema apresenta as imagens reais mais semelhantes do banco, comparadas com o retrato falado da entrada. O número de imagens apresentadas no resultado pode ser ajustado de acordo com a preferência do usuário, uma vez que as imagens já estão classificadas no ranking de similaridade obtido no processamento.

Este processo foi realizado para todas as imagens de retrato falado, ou seja, um processamento para cada classe do banco de imagens e os resultados foram registrados em uma tabela para que fossem analisados e tabulados estatisticamente e o desempenho do sistema pudesse ser avaliado.

\subsubsection{Avaliação de Desempenho}

Recall X Precision é um método de avaliação de desempenho da busca baseado na relevância, sendo Recall a probabilidade de uma amostra relevante ser recuperada e Precision a probabilidade de que uma amostra recuperada seja relevante. No seu gráfico, quanto mais próximo do topo ficar sua curva, melhor é o desempenho do método de busca. Recall X Precision foi aplicado no conjunto com 134 classes de indivíduos diferentes, sendo cada classe composta por 4 imagens da mesma face em poses diferentes mais um retrato falado correspondente à classe .

Cumulative Match Score (CMS) pode ser aplicado em universo aberto ou fechado. No caso de universo aberto, algum(ns) elemento(s) do conjunto de teste não pertence $(\mathrm{m})$ a nenhuma classe do conjunto de treinamento. Operando em universo fechado, todos os elementos do conjunto de teste podem ser mapeados a uma classe do conjunto de treinamento. A princípio utilizou-se universo aberto, já que o retrato falado não pertence ao conjunto das imagens de face onde as buscas serão realizadas.

Para demonstrar os resultados em CMS foram utilizados dois conjuntos: um com 134 classes de esboços gerados pelo Misturograma e outro com 134 classes das mesmas imagens, mas geradas por meio do retrato falado. Este último conjunto é chamado de conjunto de buscas. 


\subsection{Considerações Finais}

Diante das metodologias pesquisadas, o uso do Misturograma para obter o esboço para se comparar com o retrato falado demonstrou ser uma boa alternativa, pois supera o desafio de se comparar imagens de faces reais com retratos falados.

Trata-se de uma tecnologia inovadora que viabiliza a comparação e ainda abre campo para novos estudos.

A criação de sub-partes simplificou o processo de criação de retrato falado favorecendo a combinação das partes de forma a abreviar o tempo que se leva para criar um retrato falado.

A decomposição das imagens por wavelet de Haar até seu sétimo nível possibilita uma grande redução de dimensionalidade das imagens, resultando em um vetor de características reduzido, abrindo uma possibilidade para futura otimização de desempenho. 


\section{Capítulo 5}

\section{Resultados e Conclusões}

"Mais fácil desintegrar um átomo que um preconceito." 


\subsection{Resultados}

Os primeiros resultados apresentados por Cumulative Match Score (CMS) foram obtidos utilizando os seguintes conjuntos:

A. Conjunto de Testes: imagens coloridas de faces, contendo 134 faces distintas compondo 134 classes.

B. Conjunto de Esboços das imagens de face, onde, cada esboço é resultado de uma imagem de face colorida do conjunto A processada pelo Misturograma. Este conjunto possui 134 imagens de esboço.

C. Conjunto de Buscas: contendo 134 imagens de retratos falados. Cada retrato falado corresponde a uma imagem de face do conjunto A. Portanto, o conjunto $C$ é constituído também de 134 classes, onde, cada classe possui apenas um representante e está relacionada a uma classe do conjunto $A$.

Os indivíduos de $\mathrm{C}$ foram submetidos à busca em $\mathrm{B}$, um a um. $\mathrm{O}$ processamento aplicou a cada imagem de B um índice de similaridade ao individuo de C. Uma vez processadas as buscas, as imagens exibidas no final são as imagens de face (fotos coloridas) de $A$, que estão indexadas às imagens de $B$.

Em aproximadamente $95 \%$ dos casos, a imagem classificada em primeiro lugar no conjunto $B$ foi uma imagem da classe correspondente em $C$, isto é, a que representava maior grau de similaridade com o retrato falado ( $R a n k=1)$. O sistema atinge $100 \%$ de acertos quando o resultado exibe até a quarta posição (Rank $=4)$, conforme pode ser observado na tabela de Cumulative Match Score.

Tabela 5.1

Cumulative Match Score

\begin{tabular}{|l|c|c|c|c|c|}
\hline Rank & $\mathbf{1}$ & $\mathbf{2}$ & $\mathbf{3}$ & $\mathbf{4}$ & $\mathbf{5}$ \\
\hline Precisão \% & 95 & 98 & 98 & 100 & 100 \\
\hline
\end{tabular}

O gráfico da figura 5.1 demonstra a curva CMS da tabela 5.1. 


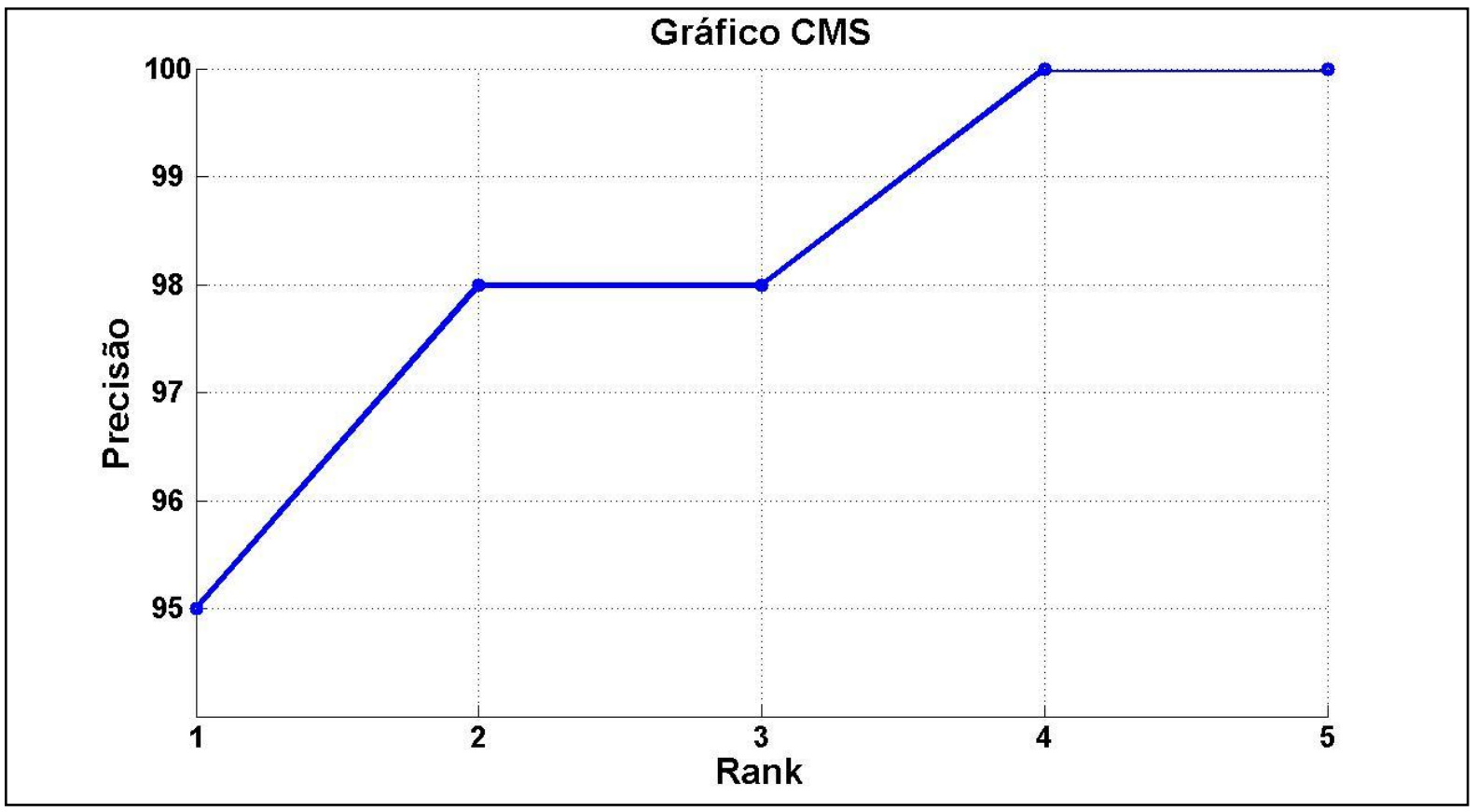

Figura 5.1: Gráfico de Cumulative Match Score para o desempenho do sistema.

Para uma análise mais detalhada foram utilizados os conjuntos originais, conforme a descrição a seguir:

A. Conjunto A: ficou constituído de 536 faces mais 134 retratos falados, totalizando 670 imagens agrupadas em 134 classes, cada classe de indivíduos com 4 imagens, em diferentes poses mais um retrato falado correspondente.

B. Conjunto B: 536 imagens do Conjunto A processadas pelo Misturograma, e suas resultantes mais 134 retratos falados integram o conjunto B.

C. Conjunto C: formado por 134 imagens de retratos falados. Cada retrato falado corresponde a uma classe do conjunto A e B.

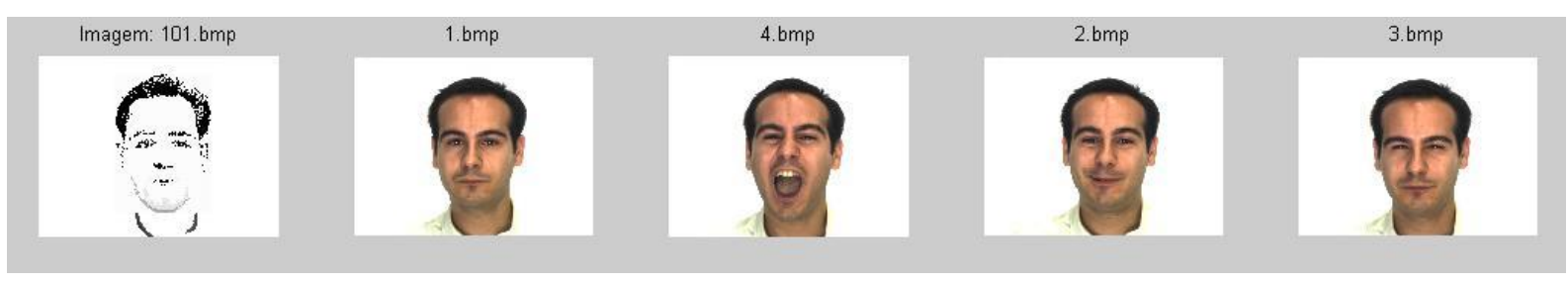

Figura 5.2: Resultado da busca por similaridade das quatro faces mais semelhantes do conjunto de testes, comparando-se o esboço com o retrato falado. 100\% das quatro imagens mais similares pertencem à classe original a qual o retrato falado foi baseado. 
Para demonstrar os resultados utilizando recall $\mathrm{X}$ precision, aplicou-se a mesma busca dos indivíduos de C (retratos falados) submetidos em B (esboços), exibindo as correspondentes de A (imagens de faces), desta vez, recuperou-se a própria imagem do retrato falado e mais quatro imagens mais semelhantes para cada retrato falado submetido à busca. Para cada posição das quatro imagens recuperadas preenchidas por uma imagem da classe a que se refere o retrato falado foi considerado um acerto. O exemplo da figura 5.2 representa um caso onde as quatro posições das quatro imagens recuperadas foram preenchidas com imagens da mesma classe, ou seja, foram obtidos quatro acertos.

Analisando-se o resultado obtido da aplicação desta busca para toda a base, tem-se os seguintes valores:

1. Para a primeira posição da recuperação o sistema deveria trazer a própria imagem do retrato falado, uma vez que é a imagem mais semelhante presente na base. Para a demonstração dos resultados de recall X precision o retrato falado está incluso na base de busca. Para a primeira posição o sistema obteve $100 \%$ de precisão, sempre recuperando na primeira posição o próprio retrato falado submetido à busca;

2. Para a segunda posição de cada busca o sistema deveria recuperar a primeira imagem esboço da classe correspondente ao retrato falado submetido à busca atual, e exibir sua imagem de face correspondente. É considerado acerto quando na segunda posição o sistema exibe qualquer uma das quatro imagens de face que compõe a classe correspondente. Em aproximadamente $95 \%$ dos retratos falados submetidos à busca, a segunda posição foi preenchida com uma das 4 imagens de face membro da sua respectiva classe;

3. Na terceira posição o sistema deveria recuperar a segunda imagem da classe. Para a terceira posição o sistema obteve precisão aproximada de $78 \%$.

4. Em aproximadamente $63 \%$ das buscas realizadas com os retratos falados a quarta posição foi preenchida com uma imagem da classe correspondente ao retrato falado submetido à busca atual;

5. Finalmente, para a quinta posição, em $50 \%$ dos retratos falados submetidos à busca, o sistema recuperou uma imagem da sua respectiva classe. 
Tabela 5.2

Precisão com 5 imagens recuperadas separadamente

\begin{tabular}{|l|c|c|c|c|c|}
\hline Posição da Classe & $\mathbf{1}$ & $\mathbf{2}$ & $\mathbf{3}$ & $\mathbf{4}$ & $\mathbf{5}$ \\
\hline Precisão \% & 100 & 95 & 78 & 63 & 50 \\
\hline
\end{tabular}

No gráfico da figura 5.3 pode-se observar o resultado das cinco imagens recuperadas conforme a tabela 5.2 , onde a precisão de recuperação é considerada separadamente para cada uma das cinco imagens. Neste caso, a composição do resultado, traz na primeira posição a própria imagem que está integrada a base de busca, por isso 5 imagens ao invés de quatro.

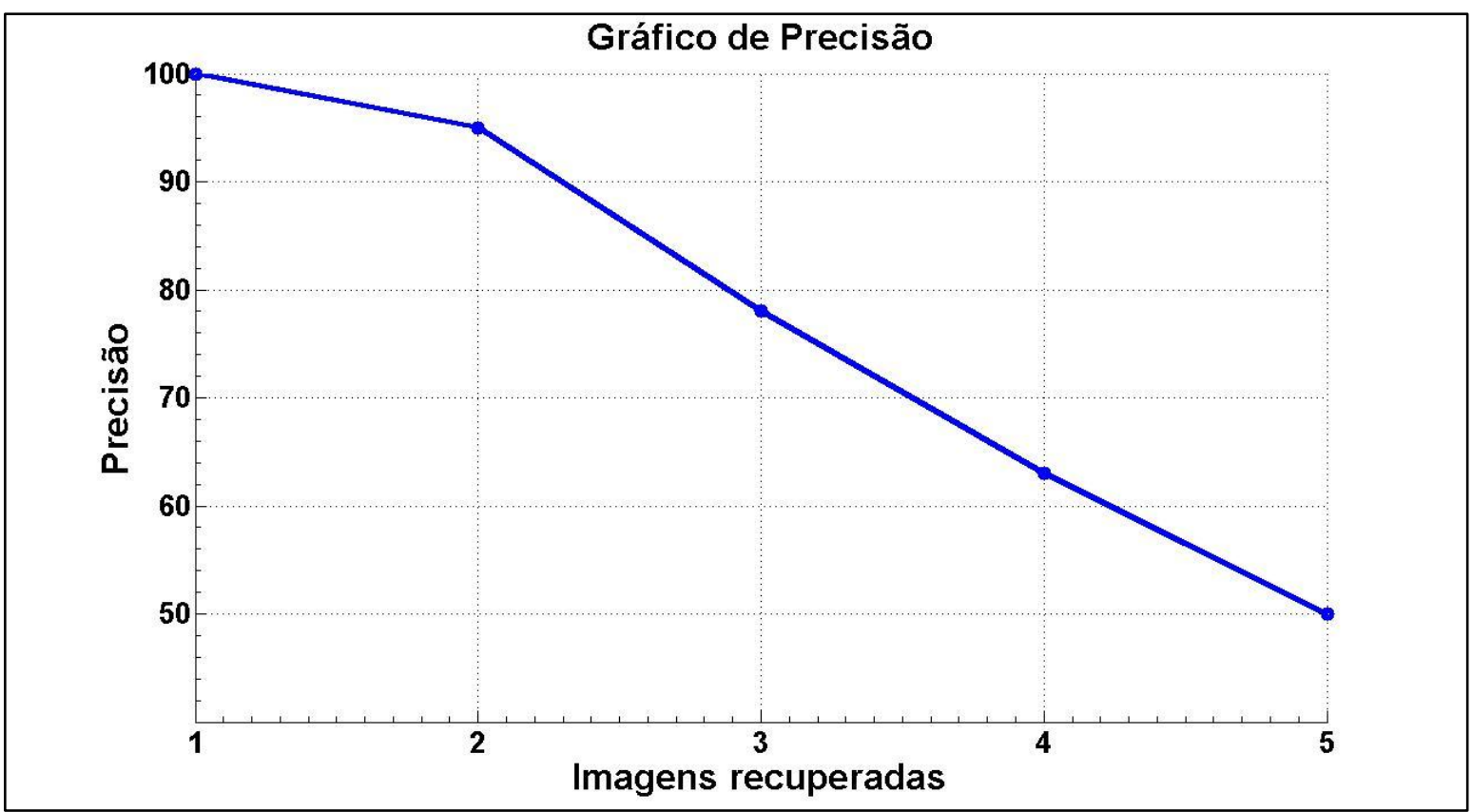

Figura 5.3: Precisão considerando a recuperação das cinco imagens separadamente.

Para o próximo passo, o resultado da recuperação foi avaliado em conjunto, onde a precisão é apresentada de forma cumulativa, somando os resultados a cada iteração. Os números dessa avaliação estão apresentados na Tabela 5.3.

Tabela 5.3

Precisão com 5 imagens recuperadas cumulativamente

\begin{tabular}{|c|c|c|c|c|c|}
\hline Imagem recuperada & $\mathbf{1}$ & $\mathbf{2}$ & $\mathbf{3}$ & $\mathbf{4}$ & $\mathbf{5}$ \\
\hline No de imagens recuperadas & 134 & 268 & 402 & 536 & 670 \\
\hline Acertos & 134 & 261 & 365 & 449 & 516 \\
\hline Precisão \% & 100 & 97 & 91 & 84 & 77 \\
\hline
\end{tabular}


O gráfico da figura 5.4 apresenta a curva resultante da média do resultado das cinco imagens de cada classe quando o retrato falado faz parte do conjunto de busca, conforme os números da tabela 5.3.

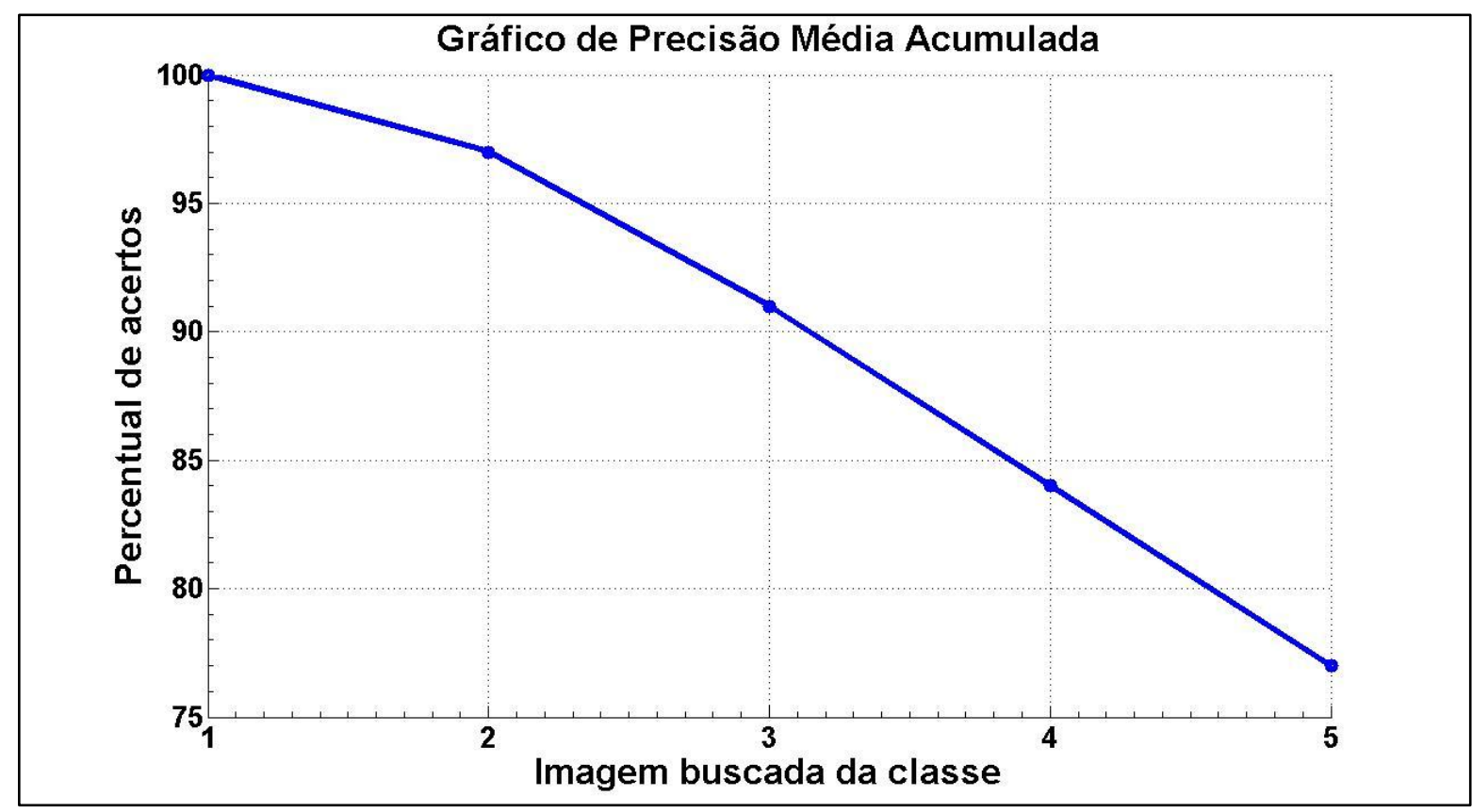

Figura 5.4: Precisão média percentual acumulada acrescentando cada imagem da classe desejada, incluindo-se o próprio retrato falado no conjunto de busca.

Para analisar a eficácia do sistema que se pretende comparar retratos falados com imagens de face, desconsiderou-se, então, a primeira posição, uma vez que ela traz o resultado da comparação do retrato falado consigo mesmo analisando apenas as quatro posições depois do próprio retrato falado, ou seja, da segunda até a quinta posição. Deste modo, os conjuntos utilizados ficaram da seguinte forma:

A. Conjunto A: ficou constituído de 536 faces agrupadas em 134 classes, cada classe de indivíduos com 4 imagens, em diferentes poses.

B. Conjunto B: todas as imagens do Conjunto A (536) foram processadas pelo Misturograma, e suas resultantes integram o conjunto $B$.

C. Conjunto C: formado por 134 imagens de retratos falados. Cada retrato falado corresponde a uma classe do conjunto A e B.

1. Das primeiras 134 imagens da classe recuperadas para cada um dos 134 retratos falados, 127 pertenciam à classe desejada. Aproximadamente, 95\% de precisão; 
2. Incorporando a terceira coluna, portanto, a segunda imagem da classe, temse 268 posições possíveis, das quais, 231 foram preenchidas com imagens da classe desejada, que corresponde a $86 \%$, aproximadamente;

3. Para as 402 primeiras posições, obtidas ao incorporar a quarta coluna, referente à terceira imagem da classe, aproximadamente $78 \%$ das imagens eram da classe desejada, ou 315 acertos;

4. Finalmente, incorporando-se a quinta coluna, para a quarta imagem da classe, para as 536 posições da busca, aproximadamente $71 \%$ estavam preenchidas com imagens reais da classe correspondente, ou 382 acertos.

Esses valores estão relacionados na tabela 5.4 .

Tabela 5.4

Precisão com 4 imagens reais recuperadas

\begin{tabular}{|c|c|c|c|c|}
\hline Imagem recuperada & $\mathbf{1}$ & $\mathbf{2}$ & $\mathbf{3}$ & $\mathbf{4}$ \\
\hline № de imagens recuperadas & 134 & 268 & 402 & 536 \\
\hline Acertos & 127 & 231 & 315 & 382 \\
\hline Precisão \% & 95 & 86 & 78 & 71 \\
\hline
\end{tabular}

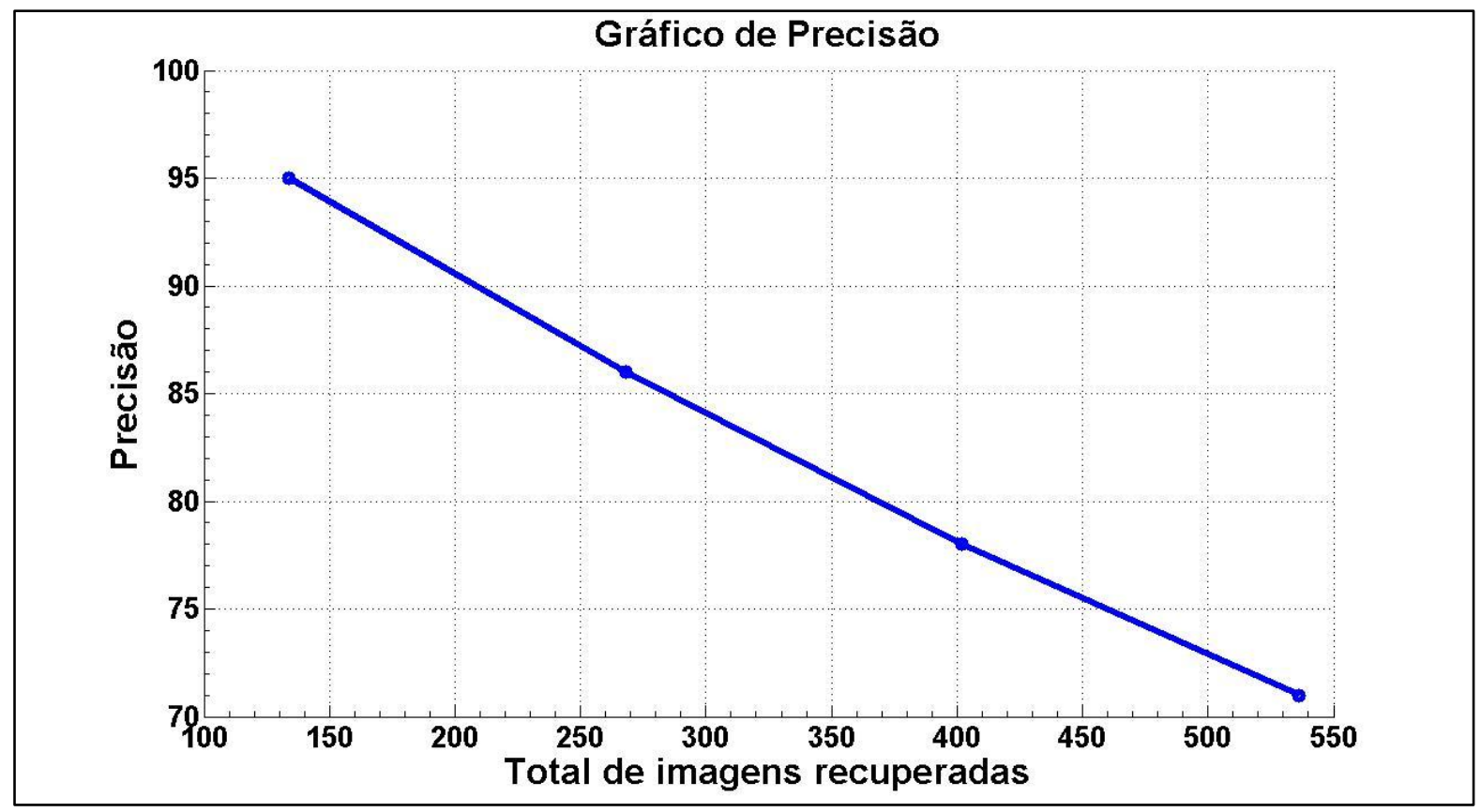

Figura 5.5: Gráfico de Precisão considerando-se apenas as quatro imagens reais da classe para a recuperação a partir do retrato falado correspondente. 
No gráfico da figura 5.5 pode-se observar a precisão da busca considerando o conjunto solução com as quatro imagens de face da classe correspondente ao retrato falado. Cada ponto destacado na curva do gráfico mostra o resultado para cada uma das quatro imagens de todas as classes.

Para representar o resultado em conjunto, ou seja, considerando as 4 imagens de face mais o retrato falado em um único resultado, utilizou-se a curva de RecallX Precision.

A curva no gráfico da figura 5.4 representa o resultado de Recall X Precision considerando o conjunto solução com as 4 imagens reais da classe mais o retrato falado correspondente. No gráfico pode-se observar os cinco pontos destacados, que representam o resultado para o próprio retrato falado e as quatro imagens do conjunto solução, respectivamente.

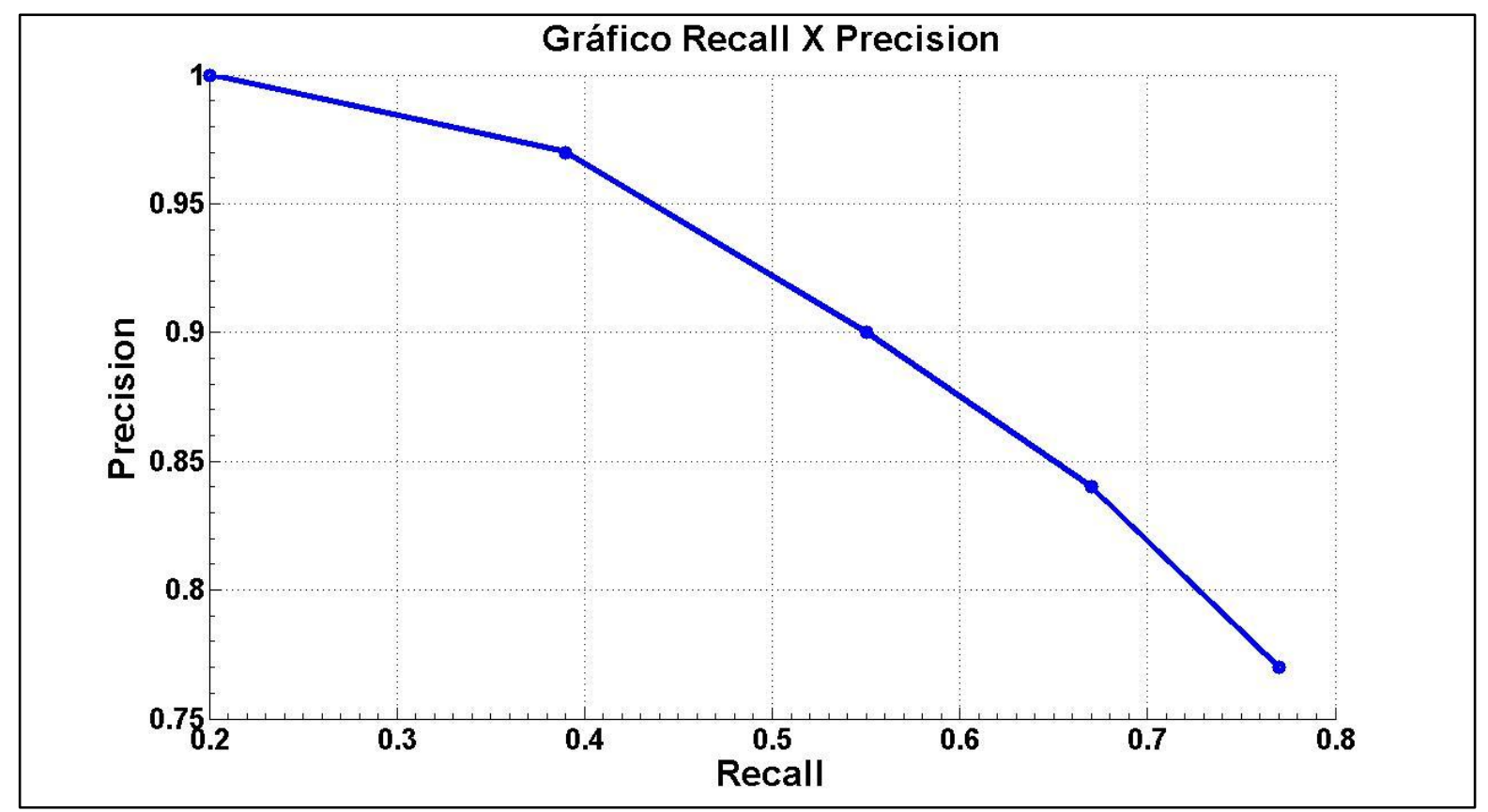

Figura 5.6: Gráfico de Recall X Precision considerando as quatro imagens reais da classe, mais o próprio retrato falado correspondente à classe como conjunto solução.

Os valores de cada ponto do gráfico da figura 5.6 estão na tabela 5.5. Esses valores representam a média de Recall e Precision para as 134 classes. 
Tabela 5.5

Média dos valores de Recall X Precision das Buscas

\begin{tabular}{|l|c|c|c|c|c|c|c|c|c|c|}
\hline Busca & \multicolumn{2}{|c|}{$\mathrm{K}=\mathbf{1}$} & \multicolumn{2}{c|}{$\mathrm{K}=\mathbf{2}$} & \multicolumn{2}{c|}{$\mathrm{K}=\mathbf{3}$} & \multicolumn{2}{c|}{$\mathrm{K}=\mathbf{4}$} & \multicolumn{2}{c|}{$\mathrm{K}=\mathbf{5}$} \\
\hline \multirow{2}{*}{} & Recall & Precision & Recall & Precision & Recall & Precision & Recall & Precision & Recall & Precision \\
\cline { 2 - 10 } & 0,2 & 1 & 0,39 & 0,97 & 0,55 & 0,9 & 0,67 & 0,84 & 0,77 & 0,77 \\
\hline
\end{tabular}

Analisando-se os dados apresentados no gráfico da figura 5.6, tem-se a média de cada ponto:

1. O primeiro ponto $(K=1)$ representa a recuperação do próprio retrato falado. Nesse ponto a média é de $100 \%$ e Precision igual a 1 e Recall igual a 0,2.

2. O segundo ponto $(K=2)$ representa a primeira imagem de face da classe recuperada, portanto, a primeira imagem da classe mais semelhante se comparada com o retrato falado. Esse ponto apresenta Precision aproximado a 0,97 e Recall aproximado de 0,39.

3. No terceiro ponto destacado $(K=3)$, pode-se observar o resultado da segunda imagem de face da classe mais semelhante ao retrato falado correspondente. A média desse ponto apresenta Precision aproximado de 0,9 e Recall aproximado de 0,55.

4. O quarto ponto destacado $(\mathrm{K}=4)$ expressa Precision aproximado de 0,84 e Recall aproximado de 0,67 , e representa a terceira imagem de face mais semelhante da classe.

5. Por fim, o quinto e último ponto destacado no gráfico $(K=5)$, demonstra Precision aproximado de 0,77 e Recall aproximado de 0,77. Este ponto representa a quarta imagem de face da classe mais próxima do retrato falado.

\subsection{Discussão}

A Comparação dos retratos falados com as fotos de imagem de face em sistemas computacionais só é possível depois de transpor a diferença entre as duas modalidades de imagens (WANG; TANG, 2009). A aplicação da técnica do Misturograma demonstra potencial para solução deste problema (SEVERINO JR., 2009). 
Diante dos resultados obtidos com a aplicação da metodologia proposta, convém destacar a precisão obtida através de CMS que alcançou $95 \%$ para rank $=1$ no reconhecimento de faces reais a partir de seus respectivos retratos falados. Confrontando tal precisão com a obtida pelos outros trabalhos existentes na literatura, comprova-se o bom desempenho do método proposto. Infelizmente, a comparação com outros métodos é apenas qualitativa, considerando-se seus índices de precisão obtidos, devido ao fato das bases de imagens utilizadas serem diferentes das utilizadas neste trabalho.

Tang e Wang (2003) através do algoritmo de "eigentransformation", utilizando CMS como métrica de avaliação de desempenho, obtiveram $97 \%$ de precisão para top dez. Se a comparação de desempenho for feita levando-se em consideração apenas o top um em CMS, que foi o nível de interesse utilizado por esta pesquisa com retratos falados, a diferença de desempenho fica mais acentuada, uma vez que o autor atesta uma precisão de $81,3 \%$ para top um. Conforme observado na figura 5.1 , o método proposto atinge $95 \%$ de precisão para top um.

Sintetizando fotos reais pelo método de multi-escala MRF, Wang e Tang (2009) obtiveram precisão de $96,3 \%$ para top um e de $99,7 \%$ para top dez.

Transformando as fotos de imagem de face em retrato falado, método que e Wang (2004) chamaram por eigenface, os autores obtiveram precisão de $71 \%$ para top um e de $96 \%$ para top dez. Tang e Wang (2004) comparam seus resultados com mais dois métodos descritos na literatura: medidas geométricas e subface.

O método de características geométricas (BRUNELLI; POGGIO, 1993) que tem como ponto forte a invariância à textura e à cor, e como ponto fraco a intolerância a variações de escala das imagens e as variações de expressões da face, utilizando CMS para avaliar a precisão, este método obteve $30 \%$ de precisão na recuperação para top um e $70 \%$ para top dez.

Já pelo método de subface, um método clássico de reconhecimento de faces (TURK; PENTLAND, 1991), a precisão de recuperação utilizando CMS como avaliador foi de $31 \%$ para top um e de $67 \%$ para top dez.

Estes dois últimos casos têm precisão em top um abaixo da precisão obtida pelos outros métodos encontrados na literatura. 
Tabela 5.6 - Precisão top um entre os métodos

\begin{tabular}{|c|c|}
\hline Método & Precisão \% \\
\hline Geométricas (BRUNELLI; POGGIO, 1993) & 30,0 \\
\hline Subface (TURK; PENTLAND, 1991) & 31,0 \\
\hline Sketch Transformation (TANG; WANG, 2004) & 71,0 \\
\hline Eigentransformation (TANG; WANG, 2003) & 81,3 \\
\hline Misturograma & 95,0 \\
\hline Multi-escala MRF (WANG; TANG, 2009) & 96,3 \\
\hline
\end{tabular}

Na tabela 5.6 é possível observar a exibição dos melhores resultados de CMS para top um, onde o método proposto, que utiliza o Misturograma em seu processamento, é comparado com os resultados dos principais métodos encontrados na literatura que utilizam retratos falados para recuperar imagens reais.

\subsection{Conclusões}

Este trabalho propõe uma nova metodologia para realizar a comparação entre imagens de faces humanas e retratos falados. Esta técnica permite a busca em banco de imagens de faces humanas baseando-se no conteúdo do retrato falado.

Essa busca é realizada pelo processamento das imagens de faces humanas pelo método do misturograma, pelo qual se obtém a imagem esboço da face, comparável com o retrato falado, oferecendo dessa forma, uma alternativa interessante para viabilizar a comparação de imagens de categorias diferentes (face humana $\mathrm{X}$ retrato falado), o que tem sido um desafio para pesquisas envolvendo CBIR a partir do retrato falado.

Para facilitar a criação de retratos falados, um banco de sub-partes da face foi criado, uma técnica já utilizada por softwares específicos para criação de retratos falados. Esse banco possui diversas partes da face humana, como cabelos, olhos, bocas, sobrancelhas e variações como óculos, barba e bigode. Os resultados 
obtidos a partir de conjuntos de imagens do mesmo indivíduo em poses diferentes demonstram que o sistema tem potencial na identificação a partir do retrato falado.

Os resultados demonstram que a comparação da imagem do esboço com o retrato falado revela-se uma alternativa eficaz; por representar uma solução automática para o processamento de imagens que serão posteriormente comparadas com o retrato falado. Em comparação com outros métodos de busca do retrato falado, a metodologia proposta obteve boa precisão. Por este motivo, a mesma representa uma solução viável para um dos principais problemas que incidem em pesquisas que envolvem retratos falados, que é justamente a dificuldade em se comparar imagens de modalidades diferentes.

De acordo com os resultados obtidos por este método, pode-se afirmar que o mesmo se trata de uma opção interessante para fins forenses, onde se concentram as principais aplicações dos retratos falados. Quando aplicado na identificação de suspeitos criminais ou pessoas desaparecidas, permite agilizar os processos de busca em bancos de imagens em domínio policial e público.

\subsection{Contribuições}

A principal contribuição deste trabalho é a proposta de um novo sistema de comparação entre imagens de faces e retratos falados e com isso, uma solução para se comparar duas imagens de modalidades diferentes.

A metodologia proposta representa um importante avanço principalmente para construção de ferramentas contra o crime, ferramentas estas que também podem auxiliar em buscas de pessoas desaparecidas. 


\section{Referências Bibliográficas}

BENSON, P. J.; PERRETT, D. I. Perception and recognition of photographic quality facial caricatures: Implications for recognition of natural images. European Journal of Cognitive Psychology, vol. 3, no. 1, p. 105 - 135, 1991.

BRUNELLI, R.; POGGIO, T. Face recognition: Features versus template. IEEE Transactions on Pattern Analysis and Machine Intelligence, vol. 15, no. 10, p. 1042 1052, 1993.

CAMPO, C. Y.; TRAINA, A. J. M. Uma Abordagem Eficiente para Recuperação de Imagens Médicas. III Workshop de Informática Médica, 2003.

ERPEN, L. R. C. Recuperação de Informação Visual. II Jornada do Conhecimento e da Tecnologia, Porto Alegre - RS - Brasil, 2000.

GONZAGA, A. Aula apresentada na Disciplina de Visão Computacional do Programa de Pós-graduação em Engenharia Elétrica da Universidade de São Paulo - Escola de Engenharia de São Carlos. 2008.

GONZALEZ, R. C.; WOODS, R. E.; EDDINS, S. L. Digital Image Prossessing using Matlab. Pearson Education, 2004.

GRACIOSO, A. C. N. R.; PARIS, A. C.; GONZAGA, A. Aplicação de Wavelets para Recuperação de Imagens Médicas por Conteúdo. Workshop de Visão Computacional (WVC'2006), São Carlos, 2006, p. 317 - 322.

HSU, R. L.; JAIN, A. K. Generating Discriminating Cartoon Faces Using Interacting Snakes. IEEE Transactions on Pattern Analysis and Machine Intelligence, Vol. 25, pp. 1388-1398, 2003.

"De acordo com a Associação Brasileira de Normas Técnicas NBR 10520. 
LIU, Q.; TANG, X.; JIN, H.; LU, H.; MA, S. A Nonlinear Approach for Face Sketch Synthesis and Recognition. Proceedings of the 2005 IEEE Computer Society Conference on Computer Vision and Pattern Recognition (CVPR'05).

LU, X.; WANG Y.; JAIN, A. K. Combining classifiers for face recognition. Proceedings of the ICME 2003, p. $13-16$.

LU, X.; WANG Y.; JAIN, A. K. Ethnicity Identification from face images. Proc. SPIE Defense and Security Symposium, Orlando, FL, April 12-16, 2004.

LU, X. Image Analysis for Face Recognition. http://www.face-rec.org/interestingpapers/General/ImAna4FacRcg_lu.pdf. Último acesso em: 12/10/2012.

MATOS, H. J. S. Reconhecimento Biométrico Baseado na Geometria da Mão. Porto 2011. 115p. Dissertação de Mestrado. Faculdade de Engenharia da Universidade do Porto.

MARTINEZ, A. M.; BENAVENTE, R. The AR Face Database. Computer Vision Center Technical Report nº 24, 1998.

MARTINS, I. Tools ergonomics for the graphic reproduction of facial images: man or computer production? Anais do Congresso Internacional de Design da Informação, Recife, Pernambuco, Brasil, 2003 a.

MARTINS, I. Retrato Falado - Uma Abordagem Prática. Documentação Técnica Software PhotoComposerplus, em 2003 b.

MARTINS, I. O comportamento criminal sob enfoque de um modelo sócioeconômico. Pesquisa de Doutorado PUC-Rio, 2005 a.

MARTINS, I. Pesquisa em bases fotográficas, a partir do retrato falado - uma solução para integração através da antropometria de Bertillon, 2005 b. 
OlIVER, N. M.; ROSARIO, B.; PENTLAND, A. P. A Bayesian Computer Vision System for Modeling Human Interactions. IEEE Transactions on Pattern Analysis and Machine Intelligence, Vol. 22, No. 8, 2000.

RIBEIRO, S. E. M. Ilustrações lápis, nanquim e cores. Silvio Ribeiro, 2005.

SANTOS, R. B. Reconhecimento de Esboços de Formas Geométricas Contidas em Fluxogramas. Goiânia, 2010. 96p. Dissertação de Mestrado. Instituto de Informática, Universidade Federal de Goiás.

SEVERINO JR., O.; GONZAGA, A. Misturograma - Uma proposta de Quantização do Histograma através da Mistura de Cores. I Workshop de Visão Computacional (WVC'2005), Piracicaba, 2005, p. $76-79$.

SEVERINO JR., O.; GONZAGA, A. Auto-esboço e Auto-pele pelo Misturograma. II Workshop de Visão Computacional (WVC'2006), São Carlos, 2006, p. 81 - 86.

SEVERINO JR., O.; GONZAGA, A. Auto-Fusão da Auto-Face, do Auto-Esboço e da Auto-pele pelo Misturograma em imagens em nível de cinza. III Workshop de Visão Computacional (WVC'2007), São José do Rio Preto, 2007, p. 64 - 68.

SEVERINO JR., O. Mistura de cores: Uma nova abordagem para processamento de cores e sua aplicação na segmentação de imagens. 2009.121f. Tese (Doutorado) Escola de Engenharia de São Carlos, Universidade de São Paulo, São Carlos, 2009.

SILVA, C. Y. V. W.; TRAINA, A. J. M. Analisando Wavelets como Geradoras de Características de Imagens para Recuperação por Conteúdo. II Workshop de Visão Computacional, São Carlos, 2006 a, p. 75-80.

SILVA, C. Y. V. W.; TRAINA, A. J. M. Recuperação de Imagens Médicas por Conteúdo Utilizando Wavelets e PCA. X Congresso Brasileiro de Informática em Saúde, Florianópolis. Anais do CBIS'2006. São Paulo : Sociedade Brasileira de Informática e Saúde, 2006 b. v. 1. p. 811-816. 
TANG, X.; WANG, X. Face Sketch Synthesis and Recognition. Proceedings of the Ninth IEEE International Conference on Computer Vision 2003 (ICCV'03).

TANG, X.; WANG, X. Face Photo Recognition Using Sketch. IEEE International Conference on Image Processing, 2002, pp. 257-260.

TANG, X.; WANG, X. Face Sketch Recognition. IEEE Transactions on Circuits and Systems for Video Technology, Vol. 14, No. 1, 2004.

TURK, M.; PENTLAND, A. Eigenfaces for recognition. Journal of Cognitive Neuroscience. Vol. 3, no. 1, p. 71 - 86, 1991.

UHL, R. G.; LOBO, N. d. V. A Framework for Recognizing a Facial Image from a Police Sketch. Proc. IEEE Conf. Computer Vision and Pattern Recognition, pp.586593, 1996.

ZHAO, W.; CHELLAPPA, R.; ROSENFELD, A.; PHILLIPS, P. J. Face Recognition: A Literature Survey. CVL Technical Report, Center for Automation Research, Univ. of Maryland at College Park, http://www.cfar.umd.edu/ftp/TRs/FaceSurvey.ps.gz, 2003.

WANG, X.; TANG X. Face Photo-Sketch Synthesis and Recognition. IEEE Transactions on Pattern Analysis and Machine Intelligence 2. IEEEXplore Digital Library, v. 31, n. 11, p. 1955-1967, 2009. 


$$
\begin{aligned}
& \text { (1) } 82 \\
& \text { 12 } 2 \text { 뇨 } \\
& \text { - } 2 \text { \& } \\
& \text { \& } 12 \\
& 1 \text { \& } 1
\end{aligned}
$$


A $\mathrm{A} A$

- $2 \mathrm{a}$

ก量 2

2 요 0

요 $\mathrm{R}$ 县 
APÊNDICE B - Amostra de Esboços gerados pelo Misturograma
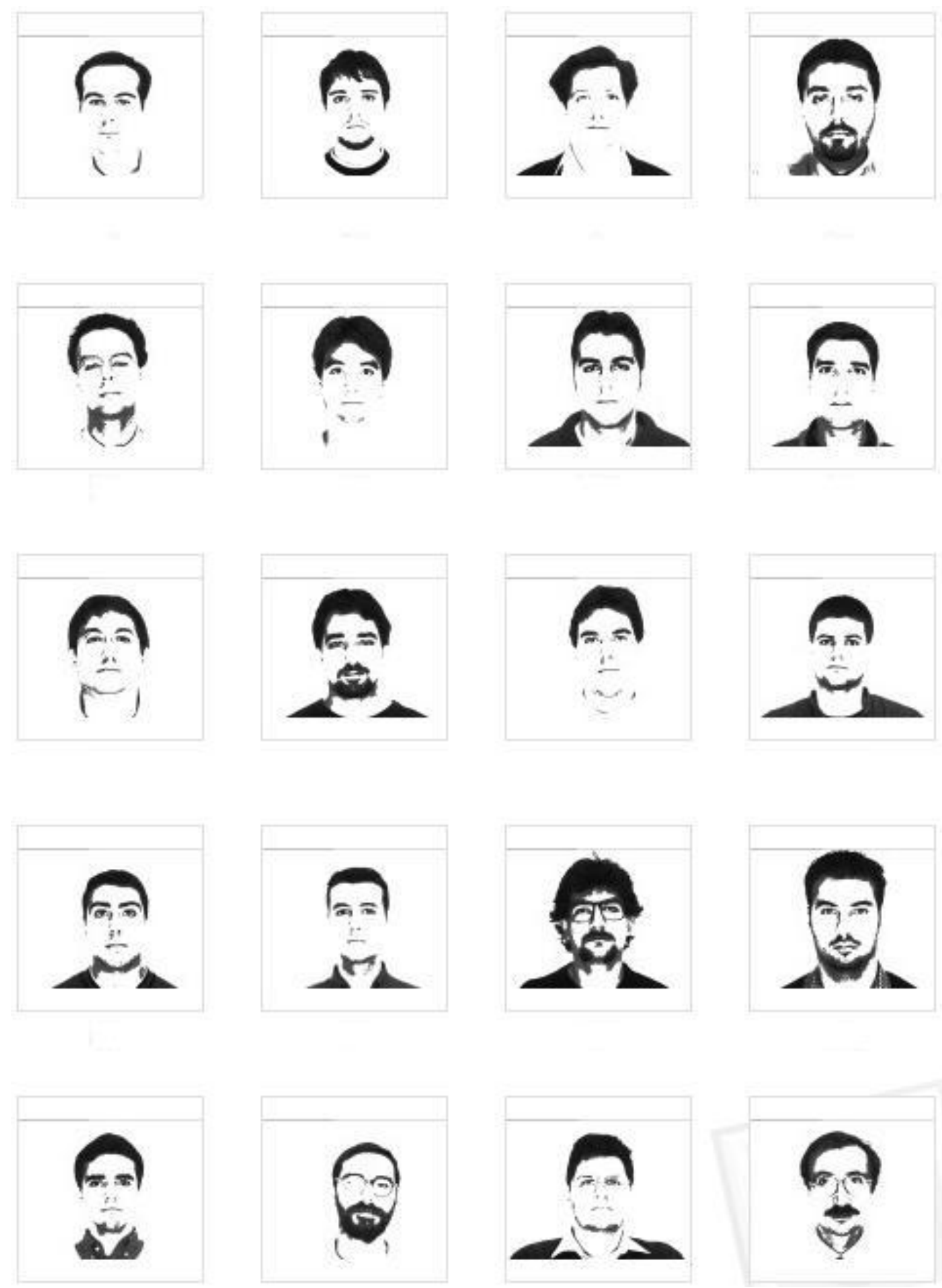

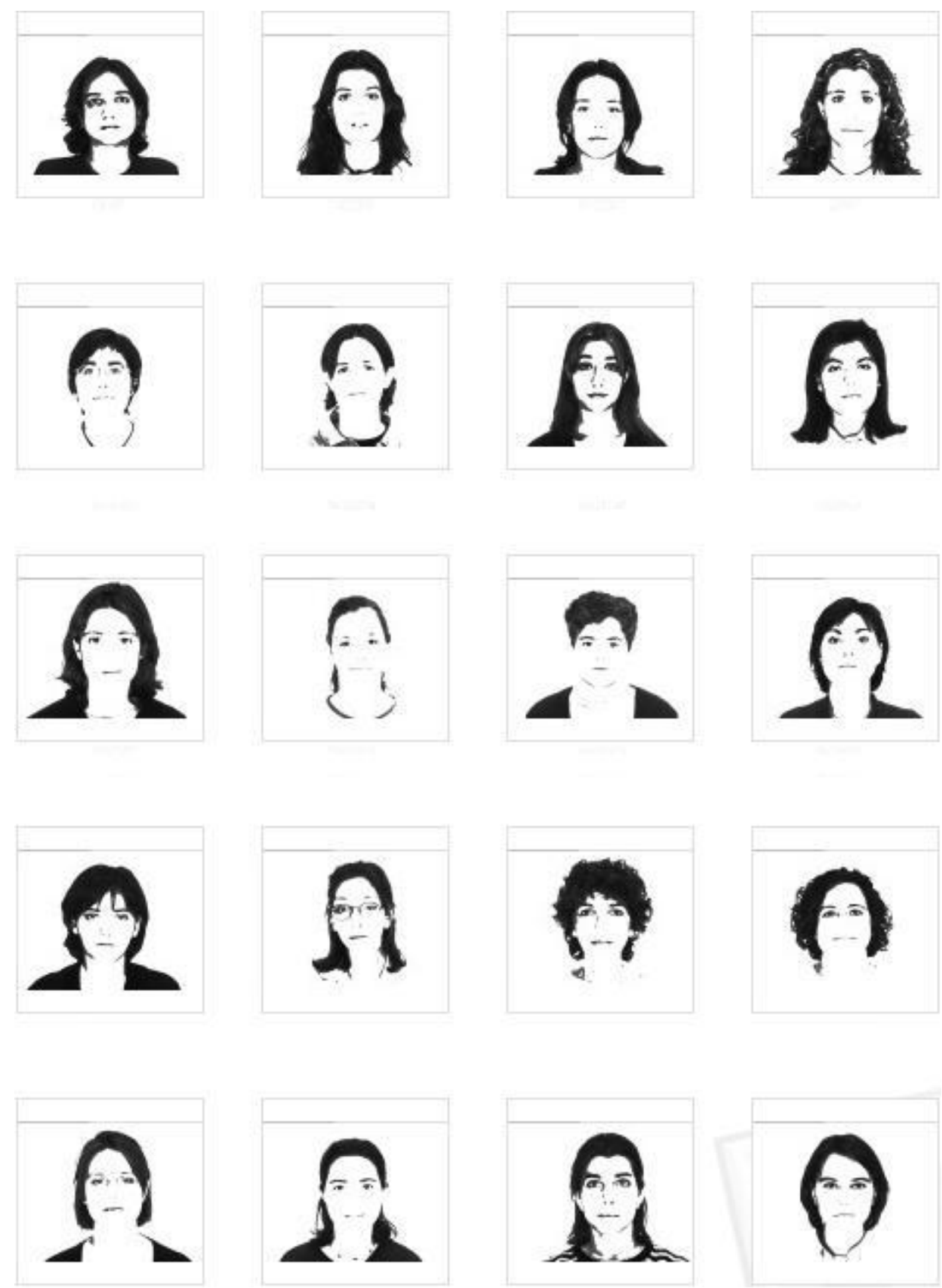
APÊNDICE C - Amostra de Retratos Falados
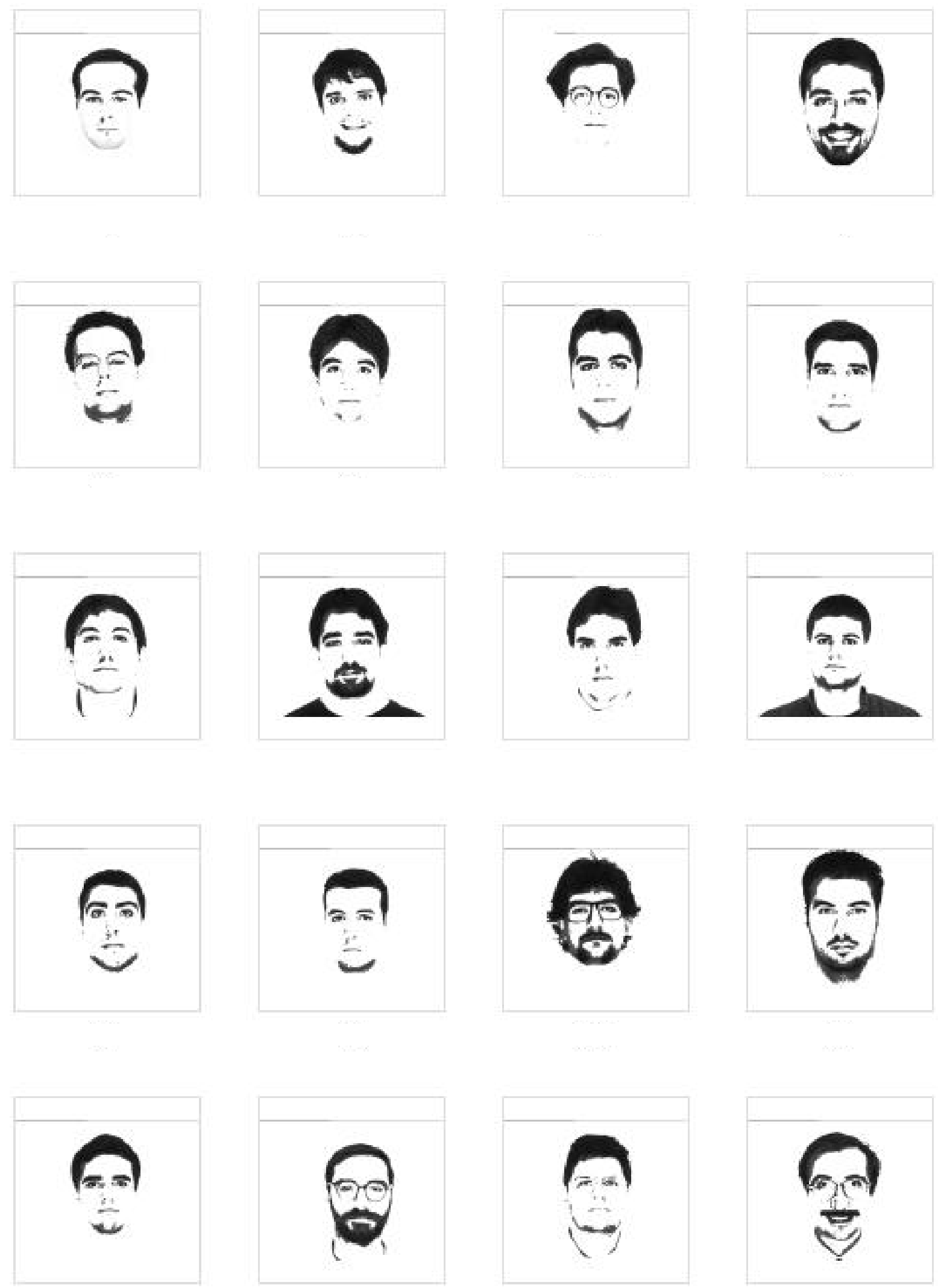


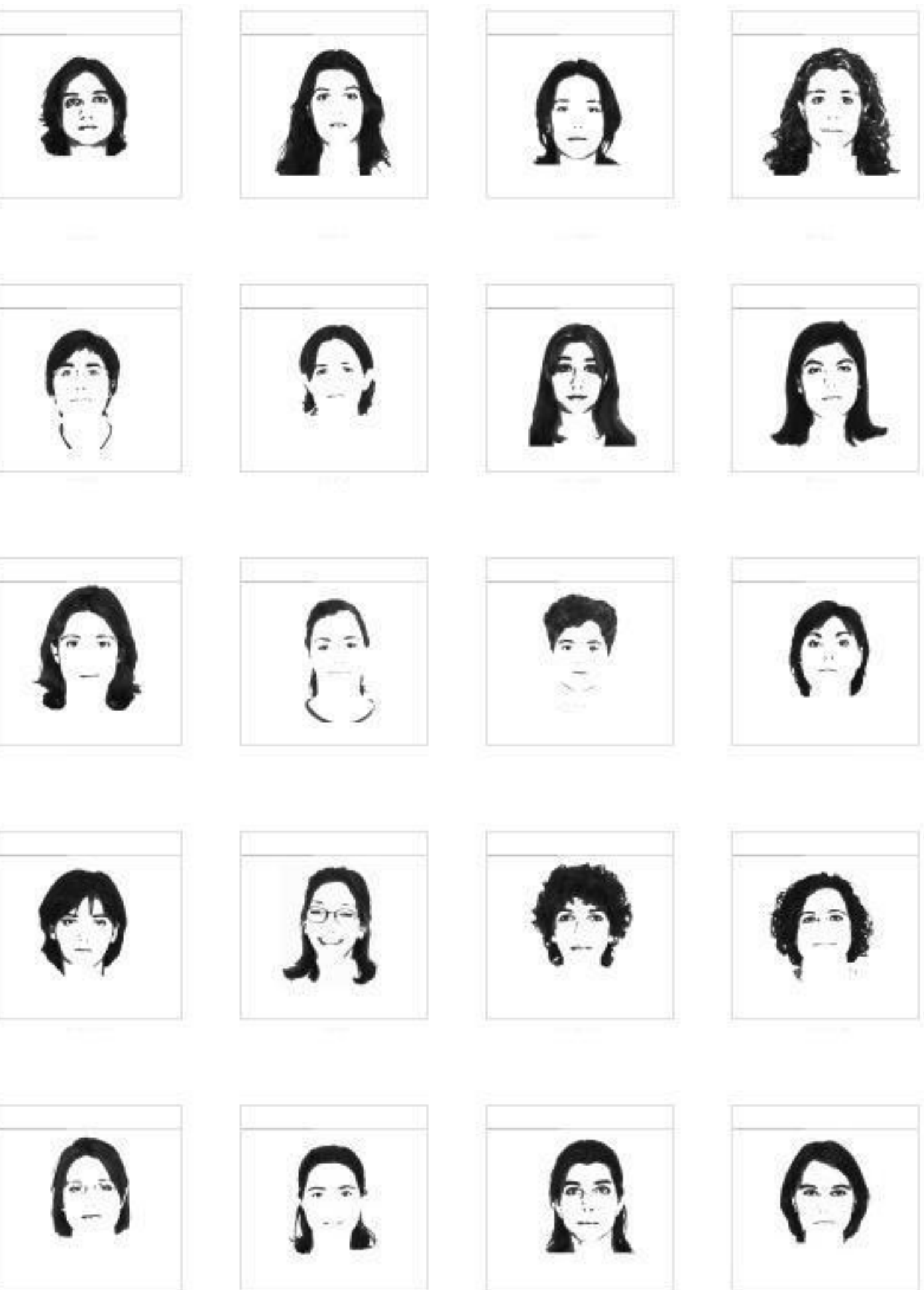

